\title{
Attaining whole-ecosystem warming using air and deep-soil heating methods with an elevated $\mathrm{CO}_{2}$ atmosphere
}

\author{
Paul J. Hanson ${ }^{1}$, Jeffery S. Riggs ${ }^{2}$, W. Robert Nettles ${ }^{1}$, Jana R. Phillips ${ }^{1}$, Misha B. Krassovski ${ }^{1}$, Leslie A. Hook ${ }^{1}$, \\ Lianhong $\mathrm{Gu}^{1}$, Andrew D. Richardson ${ }^{3}$, Donald M. Aubrecht ${ }^{3}$, Daniel M. Ricciuto ${ }^{1}$, Jeffrey M. Warren ${ }^{1}$, and \\ Charlotte Barbier ${ }^{4}$ \\ ${ }^{1}$ Climate Change Science Institute, Oak Ridge National Laboratory, Oak Ridge, Tennessee, USA \\ ${ }^{2}$ Integrated Operations Support Division, Oak Ridge National Laboratory, Oak Ridge, Tennessee, USA \\ ${ }^{3}$ Department of Organismic and Evolutionary Biology, Harvard University, Cambridge, Massachusetts, USA \\ ${ }^{4}$ Instrument and Source Division, Oak Ridge National Laboratory, Oak Ridge, Tennessee, USA \\ Correspondence to: Paul J. Hanson (hansonpj@ornl.gov)
}

Received: 18 October 2016 - Discussion started: 1 November 2016

Revised: 3 February 2017 - Accepted: 7 February 2017 - Published: 24 February 2017

\begin{abstract}
This paper describes the operational methods to achieve and measure both deep-soil heating (0-3 m) and whole-ecosystem warming (WEW) appropriate to the scale of tall-stature, high-carbon, boreal forest peatlands. The methods were developed to allow scientists to provide a plausible set of ecosystem-warming scenarios within which immediate and longer-term (1 decade) responses of organisms (microbes to trees) and ecosystem functions (carbon, water and nutrient cycles) could be measured. Elevated $\mathrm{CO}_{2}$ was also incorporated to test how temperature responses may be modified by atmospheric $\mathrm{CO}_{2}$ effects on carbon cycle processes. The WEW approach was successful in sustaining a wide range of aboveground and belowground temperature treatments $\left(+0,+2.25,+4.5,+6.75\right.$ and $\left.+9{ }^{\circ} \mathrm{C}\right)$ in large $115 \mathrm{~m}^{2}$ open-topped enclosures with elevated $\mathrm{CO}_{2}$ treatments $(+0$ to $+500 \mathrm{ppm})$. Air warming across the entire 10 enclosure study required $\sim 90 \%$ of the total energy for WEW ranging from 64283 mega Joules $(\mathrm{MJ}) \mathrm{d}^{-1}$ during the warm season to $80102 \mathrm{MJ} \mathrm{d}^{-1}$ during cold months. Soil warming across the study required only 1.3 to $1.9 \%$ of the energy used ranging from 954 to $1782 \mathrm{MJ} \mathrm{d}^{-1}$ of energy in the warm and cold seasons, respectively. The residual energy was consumed by measurement and communication systems. Sustained temperature and elevated $\mathrm{CO}_{2}$ treatments were only constrained by occasional high external winds. This paper contrasts the in situ WEW method with closely related field-warming approaches using both aboveground (air or infrared heating) and belowground-warming methods. It
\end{abstract}

also includes a full discussion of confounding factors that need to be considered carefully in the interpretation of experimental results. The WEW method combining aboveground and deep-soil heating approaches enables observations of future temperature conditions not available in the current observational record, and therefore provides a plausible glimpse of future environmental conditions.

\section{Copyright statement}

This manuscript has been authored by UT-Battelle, LLC under contract no. DE-AC05-00OR22725 with the US Department of Energy. The United States Government retains and the publisher, by accepting the article for publication, acknowledges that the United States Government retains a nonexclusive, paid-up, irrevocable, worldwide license to publish or reproduce the published form of this manuscript, or allow others to do so, for United States Government purposes. The Department of Energy will provide public access to the results of federally sponsored research in accordance with the DOE Public Access Plan (http://energy.gov/downloads/ doe-public-access-plan). 


\section{Introduction}

Measurements through time and across space have shown that the responses of terrestrial ecosystems to both chronic and acute perturbations of climatic and atmospheric drivers can lead to changes in ecosystem structure (e.g., species composition, leaf area and root distribution; IPCC, 2014; Walther et al., 2002; Cramer et al., 2001) and ecosystem function (e.g., plant physiology, soil microbial activity and biogeochemical cycling; Bronson, 2008, 2009). The projected magnitudes and rates of future climatic and atmospheric changes, however, exceed conditions exhibited during past and current interannual variations or extreme events (Collins et al., 2013), and thus represent conditions whose ecosystem-scale responses may only be studied through manipulations at the field scale. Science working groups have focused on next generation ecosystem experiments (Hanson et al., 2008) and concluded that there is "a clear need to resolve uncertainties in the quantitative understanding of climate change impacts" and that "a mechanistic understanding of physical, biogeochemical and community mechanisms is critical for improving model projections of ecological and hydrological impacts of climate change." Furthermore, a number of reviews have recently called for new studies of climate extremes, including experimental warming to obtain measurements for warming scenarios that go beyond the observable records (Cavaleri et al., 2015; Kayler et al., 2015; Torn et al., 2015).

Consensus projections of the climatic and atmospheric changes from the Fifth Assessment Report of the Intergovernmental Panel on Climate Change (IPCC) vary spatially across the globe. Warming is, however, projected to be the greatest at high latitudes with temperature increases larger in winter than summer (Collins et al., 2013). A mean warming of as much as 2.6 to $4.8^{\circ} \mathrm{C}$ during the summer and winter respectively is expected by the end of this century, based on global carbon model calculations for the IPCC RCP8.5 scenario. That level of warming exceeds the typically observed variation in mean annual temperatures $\left( \pm 2^{\circ} \mathrm{C}\right)$ and therefore represents a range of conditions that necessitate experimental manipulation. In addition, future extreme summer heat events may expose ecosystems to acute heat stress that exceed historical and contemporary long-term conditions for which extant vegetation is adapted.

Warming has been studied using many methods in field settings with the most common methods focused on warming low stature or juvenile vegetation and surface soils using infrared heaters, small open-top chambers or near-surface heating cables - all of which have restricted warming capacities (Aronson and McNulty, 2009). This paper describes warming methodologies that take us to the other extreme: systems capable of producing warming at multiple temperature levels in larger plots $\left(>100 \mathrm{~m}^{2}\right)$ and throughout the soil profile (depths well below $1 \mathrm{~m}$ ) and above tall vegetation. The methodology was initially demonstrated in a small $12 \mathrm{~m}^{2}$ chamber (Hanson et al., 2011), scaled up to a full-sized prototype $>100 \mathrm{~m}^{2}$ (Barbier et al., 2012), then deployed into a black spruce - Sphagnum peat bog in northern Minnesota as a platform for the Spruce and Peatland Response Under Climatic and Environmental Change (SPRUCE) experiment (http://mnspruce.ornl.gov; Krassovski et al., 2015)

SPRUCE was conceived to provide whole-ecosystem experimental treatments that span a wide range of warming scenarios to improve understanding of mechanistic processes and consequential ecosystem-level impacts of warming on peatlands. SPRUCE is evaluating the response of existing in situ and tall-stature $(>4 \mathrm{~m})$ biological communities to a range of temperatures from ambient conditions to $+9^{\circ} \mathrm{C}$ for a Picea mariana (Mill.) B.S.P. (black spruce) - Sphagnum spp. peatland forest in northern Minnesota. Because this ecosystem is located at the southern extent of the spatially expansive boreal peatland forests, it is considered to be especially vulnerable to climate change, and warming is expected to have important feedbacks on the atmosphere and climate through enhanced greenhouse gas emissions (Bridgham et al., 2006; Davidson and Janssens, 2008; Strack, 2008). The primary goals of the research were to (1) test how vulnerable an important C-rich terrestrial ecosystem is to atmospheric and climatic change, (2) test if warming of the entire soil profile would release large amounts of $\mathrm{CO}_{2}$ and $\mathrm{CH}_{4}$ from a deep C-rich soil and (3) derive key temperature response functions for mechanistic ecosystem processes that can be used for model validation and improvement. SPRUCE provides an excellent opportunity to investigate how atmospheric and climatic change alter the interplay between vegetation dynamics and ecosystem vulnerability, while addressing critical uncertainties about feedbacks through the global carbon (C) and hydrologic cycles.

This paper describes the operational methods applied to achieve both deep-soil heating, or in this case, deep peat heating (DPH), and whole-ecosystem warming (WEW) appropriate to the scale of the $6 \mathrm{~m}$ tall boreal forest and underlying peat. While the primary goal for SPRUCE was to focus on the response of a high-C peatland ecosystem to rising temperatures, elevated $\mathrm{CO}_{2}\left(\mathrm{eCO}_{2}\right)$ was also incorporated into the experimental design to test how the temperature response surfaces may be modified by expected changes in atmospheric $\left[\mathrm{CO}_{2}\right]$. The paper further describes confounding factors that need to be considered carefully in the interpretation and analysis of the experimental results (Leuzinger et al., 2015). While a comprehensive literature comparison to other warming methods (Rustad et al., 2001; Shaver et al., 2000; Aronson and McNulty, 2009) was not an objective of this paper, the nature of the in situ WEW method is discussed in the context of closely related field-warming approaches deployed with both aboveground (air or infrared heating) and belowground-warming methods. 


\section{Methods}

\subsection{A brief discussion of the SPRUCE experimental infrastructure}

Experimental plots and infrastructure in support of the SPRUCE WEW study were established on the S1-Bog of the Marcell Experimental Forest (MEF; Kolka et al., 2011). Raised boardwalks were added in 2012, electrical and communication systems were added in 2013, provisions for belowground heating were added in 2014, and the aboveground enclosures and air-warming systems were added between January and June 2015. Infrastructure for the addition of $\mathrm{eCO}_{2}$ was added in 2016. Pretreatment data were collected throughout the 2012 to 2015 period.

An original plan for the SPRUCE experimental temperature and $\mathrm{CO}_{2}$ treatments included a traditional replicated ANOVA design, but a quantitative analysis of various experimental designs and discussions among experimentalists and modelers led to the conclusion that a regression-based experimental design (Cottingham et al., 2005) including a broad range of temperature levels would yield long-term data more suited for the characterization of response curves for application within ecosystem and Earth system models (see also Kardol et al., 2012). If necessary for some assessments of significant warming effects (e.g., individual tree growth), the regression combination of treatment plots might be justifiably binned into low-, medium- and high-temperature treatments for ANOVA-based analyses. An important assumption underlying this choice was that there were no strong gradients across the experimental area that would mandate a block design. Preliminary survey data from the chosen site justify making this assumption (e.g., Parsekian et al., 2012; Tfaily et al., 2014).

An aerial photograph of the SPRUCE site shows the random assignment of treatments to plots (Fig. 1). Tfaily et al. (2014) and Krassovski et al. (2015) provided details for the experimental site, which include three $\sim 100 \mathrm{~m}$ transect boardwalks for accessing 17 octagonal permanent plots over the southern half of the 8.1 ha bog. Electrical supply systems (for belowground heating and instrumentation), propane vaporizers and delivery pipelines (for forced-air heating), pure $\mathrm{CO}_{2}$ delivery pipelines (for $\mathrm{eCO}_{2}$ additions), and a data communication network (Krassovski et al., 2015) were initially installed along each transect to serve the individual permanent plots. In all, 10 of the permanent plots were randomly assigned to the following warming treatments: two fully constructed control plots with no energy added (henceforth simply control plots), and two plots each to be managed as $+2.25,+4.5,+6.75$ and $+9^{\circ} \mathrm{C}$ warming plots. Two unchambered ambient plots are also part of the experimental design. Enclosure methods for warming of the air and belowground peat are described further in the following sections.

Each of the 10 plots is surrounded beneath the surface by a corral made of interlocking vinyl sheet-pile walls (model

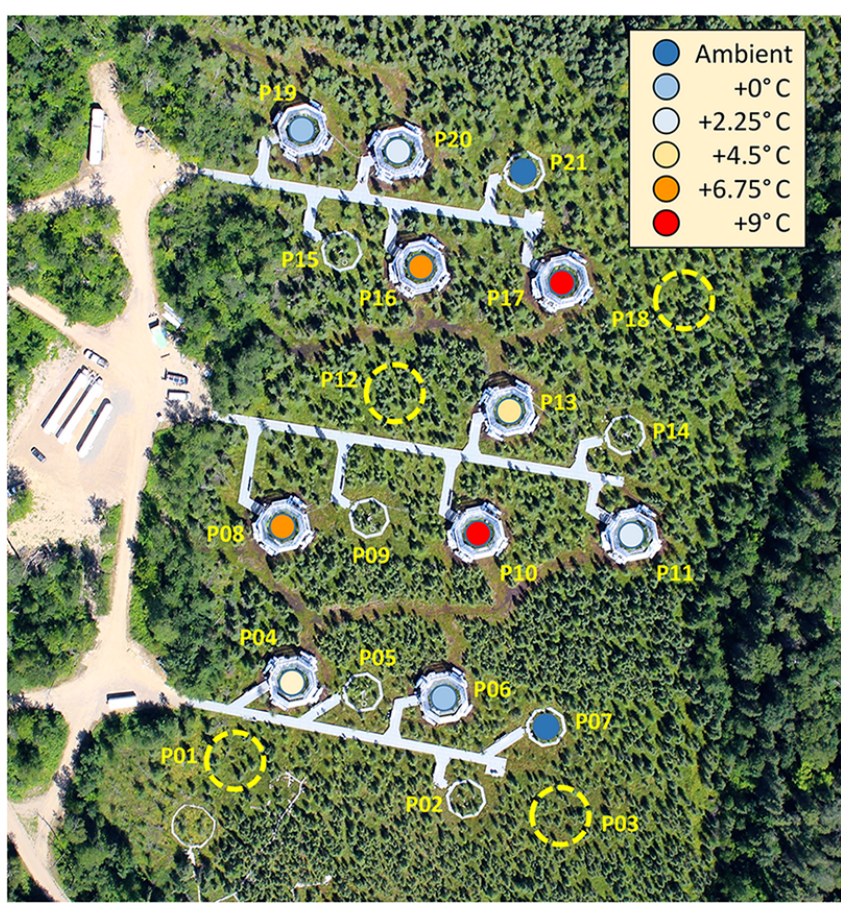

Figure 1. Aerial photograph of the SPRUCE experimental site on 5 August 2015. Plot numbers (1 to 21) and assigned temperature treatments are superimposed on the image. Dashed circles indicated established plot centers for plots that are monitored annually for tree growth. Plots $4,10,11,16$ and 19 receive elevated $\mathrm{CO}_{2}$. The middle boardwalk is $112 \mathrm{~m}$ long.

ESP 3.1, EverLast Synthetic Products, LLC) for the hydrologic isolation of each plot as an independent ombrotrophic system (Sebestyen and Griffiths, 2016). Following installation, each sheet pile extended above the bog surface approximately $0.3 \mathrm{~m}$ having been driven vertically through the peat profile ( 3 to $4 \mathrm{~m}$ ) into the underlying ancient lake sediment. Slotted outflow pipes allow for lateral drainage and hydrologic measurements and sampling from each plot. The operation and performance of the corral system will be described in a future paper. During the period of performance covered in this manuscript, the bog remained very wet with a water table near the surface, but did show transient drying (Fig. S2 in the Supplement).

\subsection{Site description}

The climate of the MEF is subhumid continental, with large and rapid diurnal and seasonal temperature fluctuations (Verry et al., 1988). Over the period from 1961 to 2005 the average annual air temperature was $3.3^{\circ} \mathrm{C}$, with daily mean extremes of -38 and $30^{\circ} \mathrm{C}$, and the average annual precipitation was $768 \mathrm{~mm}$. Mean annual air temperatures have increased about $0.4^{\circ} \mathrm{C}$ per decade over the last 40 years (Sebestyen et al., 2011). 
The investigated peatland is the S1-Bog of the MEF $\left(47^{\circ} 30.476^{\prime} \mathrm{N} ; 93^{\circ} 27.162^{\prime} \mathrm{W}\right.$; $418 \mathrm{~m}$ above mean sea level). The S1-Bog is an ombrotrophic peatland with a perched water table that has little regional groundwater influence. The S1-Bog is dominated by Picea mariana (Mill.) B.S.P. (black spruce) with contributions to the forest canopy from Larix laricina (Du Roi) K. Koch (larch). The S1-Bog trees were harvested in strip cuts in 1969 and 1974 to test the effects of seeding on the natural regeneration of $P$. mariana. All regeneration following the strip cut events occurred through natural vegetative processes or seeding events (three to four successful events since 1969). All saplings greater than $1 \mathrm{~cm}$ diameter at $1.3 \mathrm{~m}$ above the Sphagnum surface are defined as trees for the SPRUCE study. Within the interior boardwalk of each plot or enclosure the number of trees ranges from a minimum of 10 larger trees in plot 10 to a maximum of 27 trees in plot 20 for a mean number of trees per plot of between 18 and 19 whole trees. In its current state of regeneration, the canopy is $5-8 \mathrm{~m}$ tall. Tree diameters at $1.3 \mathrm{~m}$ (diameter at breast height, dbh) range from a plot mean minimums of $3.5 \mathrm{~cm}$ to plot mean maximum of $6.5 \mathrm{~cm}$ with a mean plot tree diameter of $5.2 \pm 0.9 \mathrm{~cm}$. The full range of dbh ranges from 1.2 to $11.1 \mathrm{~cm}$ across the SPRUCE experimental site in 2016.

Vegetation within the S1-Bog is dominated by two tree species (see above), and is supported by a bryophyte layer dominated by Sphagnum spp. mosses, especially $S$. angustifolium and S. fallax in hollows and S. magellanicum on drier hummocks. Other mosses including Pleurozium spp. (feather mosses) and Polytrichum spp. (haircap mosses) are also present. The understory includes a layer of ericaceous shrubs including Rhododendron groenlandicum (Oeder) Kron \& Judd (Labrador tea), Chamaedaphne calyculata (L.) Moench. (leatherleaf) with a minor component of other woody shrubs. The bog also supports a limited number of herbaceous species including the summerprevalent Maianthemum trifolium (L.) Sloboda (three-leaf false Solomon's seal), a variety of sedges (Rhynchospora alba (L.) Vahl, Carex spp.) and Eriophorum vaginatum (cotton grass). The belowground peat profile and geochemistry are described in Tfaily et al. (2014).

The peatland soil is the Greenwood series, a Typic Haplohemist (http://websoilsurvey.nrcs.usda.gov) with average peat depths to the Wisconsin glacial-age lake bed of 2 to $3 \mathrm{~m}$ (Parsekian et al., 2012). Recent surveys of the peat depth, bulk density and $\mathrm{C}$ concentrations for the S1-Bog suggest a total C storage pool of greater than $240 \mathrm{kgC} \mathrm{m}^{-2}$ (calculated to a $3 \mathrm{~m}$ average depth), with greater than $90 \%$ over 3000 years old (K. McFarlane, personal communication, 2016).

\subsection{Air-warming protocols}

Air warming was achieved by heating the air above the surface of the peatland to a height of nearly $6 \mathrm{~m}$ within open- (a)
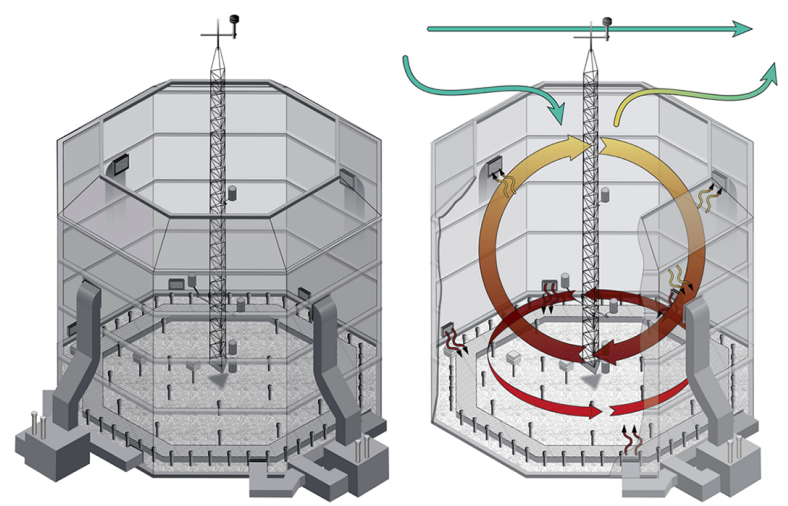

(b)

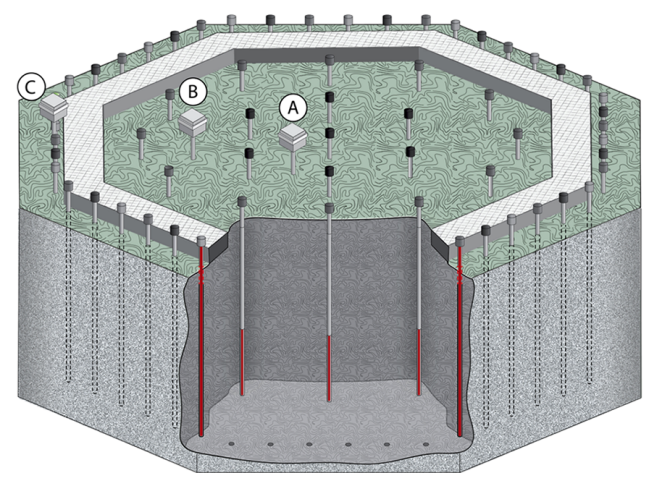

Figure 2. (a) Diagram of the air-warming enclosure, warm air flow pattern and external wind inputs leading to a homogenized air envelope that surrounds the aboveground vegetation. (b) Diagram of the belowground heater distribution pattern and the functional heating surfaces. The $100 \mathrm{~W}$ heaters are deployed in an inner section A (seven deep only heaters), middle section B (12 deep only heaters) and outer section $\mathrm{C}$ (three alternating circuits of 48 fulllength heaters).

top octagonal enclosures $(7 \mathrm{~m}$ tall by $12.8 \mathrm{~m}$ in diameter with an area of $114.8 \mathrm{~m}^{2}$; Fig. 2a). The enclosures include an octagonal open top $\left(8.8 \mathrm{~m}\right.$ diameter with an area of $\left.66.4 \mathrm{~m}^{2}\right)$ bounded by a $35^{\circ}$ frustum. The frustum was added to enhance the efficiency of the warming enclosure (Barbier et al., 2012). Wall and frustum structural members were made of structural aluminum (6061-T6 alloy), and the walls are sheathed with double-walled transparent greenhouse panels (16 $\mathrm{mm}$ acrylic glazing). The vertical walls of the enclosure sit approximately $0.46 \mathrm{~m}$ above the bog hollow surface. The gap from the bottom of the enclosure was sealed into the bog surface $(\sim 10 \mathrm{~cm})$ with flexible acrylic panels. All structures are supported above the bog on helical piles installed to a typical depth of 12 to $18 \mathrm{~m}$ below the peat surface within stable ancient lake sediments and glacial till.

Air-warming method theory, protocols and optimization of an earlier prototype were fully described by Barbier et al. (2012). Briefly, air at four mid-enclosure heights was drawn from within the enclosure down to four ground level propane indirect-fired bent tube heaters (model A2-IBT-600300-300-G15; CaptiveAire, Youngsville, NC) for variable 
heating of the air to achieve five temperature targets $(+0$, $+2.25,+4.5,+6.75$ and $+9{ }^{\circ} \mathrm{C}$ ). The pattern of airflow and air warming within a typical enclosure is depicted in Fig. 2a. Warmed air from the four heat exchangers is split into eight equal distribution conduits for distribution into the enclosure $1 \mathrm{~m}$ above the peat hollow surface through diffusers located on each wall. The control or warm air delivered into each enclosure is provided at a continuous mean velocity of $7.5 \mathrm{~m} \mathrm{~s}^{-1}$ (blower operation was initiated in 2015 as soon as each enclosure was fully glazed with greenhouse panels). These warm air streams are directed away from adjacent vegetation surfaces as much as possible and diffuse rapidly into the background mixed air of the enclosure.

The air warming described above was achieved using propane-fired heat exchangers. Propane was delivered to a large (10000 gallon) liquid propane storage tank located at the site. Liquid propane was pulled from the bottom of this tank and pumped to vaporizers located at the head of each boardwalk. Vaporized propane was then piped to the furnaces. This system allowed us to operate throughout the year including periods of ambient winter temperatures as low as $-35^{\circ} \mathrm{C}$ on 17 January 2016 .

\subsection{Peat-warming protocols}

In June 2014 when the capabilities for deep belowground warming were operational, we initiated a 13-month period of DPH treatments for the 10 constructed SPRUCE plots. The DPH method is an expanded form of the deep belowground heating approach of Hanson et al. (2011) that was rationalized as being an appropriate surrogate for deep-soil heating expected under future climate conditions (Huang, 2006; Baker and Ruschy, 1993). DPH was accomplished by an array of $3 \mathrm{~m}$ vertical low-wattage-heating $(100 \mathrm{~W})$ elements installed throughout the plots within a plastic-coated iron pipe. The belowground heating array, which was contained within the encircling subsurface corral, included circles of 48,12 and 6 heaters at 5.42, 4 and $2 \mathrm{~m}$ radii, respectively (Fig. 2b). A single heater was also installed at the plot center. Exterior heaters in the circle of 48 applied the $100 \mathrm{~W}$ across the full linear length of the heater, and all interior heaters applied their $100 \mathrm{~W}$ heating capacity to the bottom one-third of each resistance heater (pipe thread core heaters, Indeeco, St. Louis, MO). Interior heaters were different to avoid directly heating the peat volumes targeted for the measurement of response variables.

\subsection{Temperature control}

Simple proportional-integral-derivative (PID) control was used for aboveground heating based on differentials measured by duplicate sensors in the center of the plot at $+2 \mathrm{~m}$. For each aboveground heating system, the position of a liquid petroleum gas (LPG) valve in each of the four heating units was simultaneously controlled. The belowground heat- ing system controlled individual heating circuits with silicon controlled rectifiers (SCR controller: 1 phase, 1 controlled leg $240 \mathrm{~V}, 20 \mathrm{Amb} @ 42.5^{\circ} \mathrm{C}$; 4-20 mA control, Watlow model DA10-24-F0-0-00) in each of five circuits. DPH within the experimental plots was achieved through PID control of three exterior (the circle of 48 split into alternating thirds) and two interior circuits of the resistance heaters shown in Fig. 2b. The control depth was $-2 \mathrm{~m}$. The reference for air and belowground heating was the plot 6 control plot. Details for aboveground and belowground PID control are provided in the Supplement to this paper along with PID coefficients for each warming treatment.

\subsection{Elevated $\mathrm{CO}_{2}$ additions}

Logical projections from IPCC analyses and the recent evaluation of current emissions (Raupach et al., 2007; Collins et al., 2013) suggest that experimental methods might consider atmospheric $\mathrm{CO}_{2}$ concentrations at or above $800 \mathrm{ppm}$ based on current fossil fuel use. As with the warming targets, the goal of the SPRUCE infrastructure was not to simulate a specific future climate or atmospheric condition, but to include a $\left[\mathrm{CO}_{2}\right]$ representative of the high end of predicted values for the end of the century (Collins et al., 2013). The $\mathrm{eCO}_{2}$ additions were included to better understand the potential mechanism that $\mathrm{CO}_{2}$-induced enhancements of gross primary production might have on warming responses.

Pure $\mathrm{CO}_{2}$ additions were initiated in half of the treatment plots (one for each temperature manipulation) on 15 June 2016 to provide an $\mathrm{eCO}_{2}$ atmosphere approaching $900 \mathrm{ppm}$ (nominally $+500 \mathrm{ppm}$ over current conditions in 2016) during daytime hours. The selected value is purposefully higher than concentrations used in previous large $\mathrm{eCO}_{2}$ experiments (Medlyn et al., 2015), and might be expected to yield a greater response by the trees and shrubs of the S1-Bog. The following text briefly describes the mechanism for elevating $\mathrm{CO}_{2}$ within the WEW enclosures. Halfhourly assessments of $\left[\mathrm{CO}_{2}\right]$ in air were obtained at 0.5 , 1,2 and $4 \mathrm{~m}$ by continuously sampling air from plot-center tower locations via a sampling manifold. Individual elevations were sampled in series for $90 \mathrm{~s}$ over a 6 min cycle. The sampled gas stream was analyzed using an in line LiCor LI$840 \mathrm{CO}_{2} / \mathrm{H}_{2} \mathrm{O}$ gas analyzer at a flow rate of $1 \mathrm{~L} \mathrm{~min}^{-1}$.

The presence of the enclosure walls reduces air turnover within the experimental space and limits the amount of $\mathrm{CO}_{2}$ needed as compared to Free-Air $\mathrm{CO}_{2}$ Enrichment studies (e.g., Dickson et al., 2000). Source $\mathrm{CO}_{2}$ for the SPRUCE experiment was obtained from fossil-fuel-based fertilizer plants by the contracted $\mathrm{CO}_{2}$ supplier (Praxair, Inc.) and has $\partial^{13} \mathrm{C}-$ and $\Delta^{14} \mathrm{C}-\mathrm{CO}_{2}$ signatures of $\sim 54$ and $-1000 \%$, respectively. Pure $\mathrm{CO}_{2}$ from a central storage area (two 60 ton refrigerated tanks) is vaporized and transferred by pipeline to each enclosure where it is warmed and regulated before entering a mass flow control valve (model GFC77, 0 $500 \mathrm{~L} \mathrm{~min}^{-1} \mathrm{CO}_{2}, 4-20 \mathrm{~mA}$ control; Aalborg Instruments 
and Controls, Inc.). The mass flow control valve allows for variable additions of the pure $\mathrm{CO}_{2}$ to the enclosure. A typical delivery velocity for pure $\mathrm{CO}_{2}$ equals $250 \mathrm{~L} \mathrm{~min}^{-1}$, but ranges from 100 to $500 \mathrm{~L} \mathrm{~min}^{-1}$ with external wind velocities between 0.2 and $5 \mathrm{~m} \mathrm{~s}^{-1}$ to account for increasing air volume turnover. Warm air buoyancy increases with larger temperature differentials (Barbier et al., 2012) and increases air turnover rates and demands for $\mathrm{CO}_{2}$ additions.

The enclosure's regulated additions of pure $\mathrm{CO}_{2}$ are distributed to a manifold that splits the gas into four equal streams feeding each of the four air handling units (Fig. 2a), and is injected into the ductwork of each furnace just ahead of each blower and heat exchanger. Horizontal and vertical mixing within each enclosure homogenizes the air volume distributing the $\mathrm{CO}_{2}$ along with the heated air. Details of the $\mathrm{CO}_{2}$ addition algorithms as they are impacted by external winds are provided in the Supplement.

\subsection{Bog and enclosure environmental measurements}

Half-hourly mean air temperature measurements were made with thermistors (model HMP-155; Vaisala, Inc.) installed at the center of each plot at $0.5,1,2$ and $4 \mathrm{~m}$ above the surface of the peat. These same sensors included a capacitance sensor for the measurement of relative humidity. New or recalibrated sensors are deployed annually or as comparisons to other sensors suggest failure. Multipoint thermistor probes for automated mean half-hourly peat temperature measurements (W.H. Cooke \& Co. Inc, Hanover, PA) were custom designed from a $1.3 \mathrm{~cm}$ diameter $\times 0.9 \mathrm{~mm}$ wall stainless steel tube with a $7.62 \mathrm{~cm}$ stainless steel disk welded at the zero height position along the tube. All elevations within the bog are referenced to the peat surface hollows, which are defined to be an elevation of $0 \mathrm{~cm}$. An electrical termination enclosure was supported above the bog surface by a $46 \mathrm{~cm}$ extension of the measurement tube to avoid shading the bog surface at the point of measurements and to keep it above any standing water. Peat temperatures were recorded at nine depths for the designated experimental plots $(0,-5,-10$, $-20,-30,-40,-50,-100$ and $-200 \mathrm{~cm})$ at three concentric zones (one at $5.42 \mathrm{~m}$ radius, one at $3 \mathrm{~m}$ radius and one at $1 \mathrm{~m}$ radius; Fig. 2b). All integrated temperature probes were located at a midpoint between heaters in a given concentric ring of the plot. Hummock temperature measurements were also obtained in the hummocks at various elevations above the hollow surface (approximately $0,+10$, and $+20 \mathrm{~cm}$ ).

Photosynthetically active radiation (PAR) was measured with quantum sensors (LiCor Inc., LI-190R) at $2.5 \mathrm{~m}$ above the surface at a middle plot location. Supplemental $1 \mathrm{~min}$ shortwave (pyranometer, 300 to $2800 \mathrm{~nm}$ ) and longwave (4.5 to $42 \mu \mathrm{m}$ ) radiation observations were also measured using matched net radiometers (model CNR4, Kipp and Zonen) for unchambered ambient and within-enclosure locations for selected mid-summer days to further characterize the enclosure environment.
Soil water content is difficult to measure in heterogeneous, low-density organic soils. Nevertheless, volumetric water content was measured within hummocks at two depths $(0 \mathrm{~cm}$ at the hollow surface, and $20 \mathrm{~cm}$ below hummock surface) at three locations within each plot using a capacitance/frequency domain sensor (10HS, Decagon Devices Inc.). These sensors required site-specific calibration (Supplemental Fig. S1).

External wind sensors at $+10 \mathrm{~m}$ above the center of each enclosure (Windsonic 4; Gill Instruments) provided important information necessary to estimate the mixing of ambient air into the enclosure space. A mobile three-dimensional (3-D) sonic anemometer (Campbell Scientific Inc., Logan, Utah; model CSAT3B) was also temporarily deployed inside and outside of plot 6 to characterize the nature of turbulence changes inside and outside of the enclosures.

\subsection{Image collections}

Infrared imaging of the internal air space was done periodically to evaluate the spatial pattern of heating of biological surfaces within the warming enclosures. Images were collected with a thermal imaging camera (TiR4 no. 2816061, Fluke Corporation, Everett, WA) with a $20 \mathrm{~mm} \mathrm{~F} / 0.88_{-}$ $14 \mu \mathrm{m}$ lens. Images were taken at the entrance of each enclosure (or unchambered ambient space) immediately after the door was opened. All images in a comparative series were collected before or after sunset within $20 \mathrm{~min}$ of one another (the time it takes to move about the SPRUCE site).

Whole-plot visible wavelength image cameras (StarDot NetCam SC Series SD130BN 1.3MP MJPEG Hybrid Color Day/Night IP Box Camera with $4 \mathrm{~mm}$ lens) were installed as a part of the PHENOCAM network (Keenan et al., 2014; Toomey et al., 2015). These cameras provide a view of the entire enclosure area. The whole-plot imaging cameras record visible (400-700 $\mathrm{nm}$ ) and visible plus infrared (400$1000 \mathrm{~nm}$ ) images sequentially, allowing for the calculation of NDVI-type indices (Petach et al., 2014). They are installed on the southern wall of each enclosure at a height of $6 \mathrm{~m}$. Current and archived PHENOCAM images for the SPRUCE plots can be found at https://phenocam.sr.unh.edu/webcam/ gallery/.

\subsection{Energy balance modeling}

The energy balance in the S1 bog, both inside and outside the enclosures, was simulated using the Community Land Model (CLM) version 4.5 (Oleson et al., 2013), which was modified to represent the specific hummock-hollow microtopography, runoff and subsurface drainage at the S1-Bog (Shi et al., 2015). This CLM-SPRUCE model was driven by meteorological data collected by the environmental monitoring stations in the S1-Bog between 2011 and 2015. Enclosure impacts on both incoming longwave and shortwave radiation were also considered in the simulations. The incoming long- 

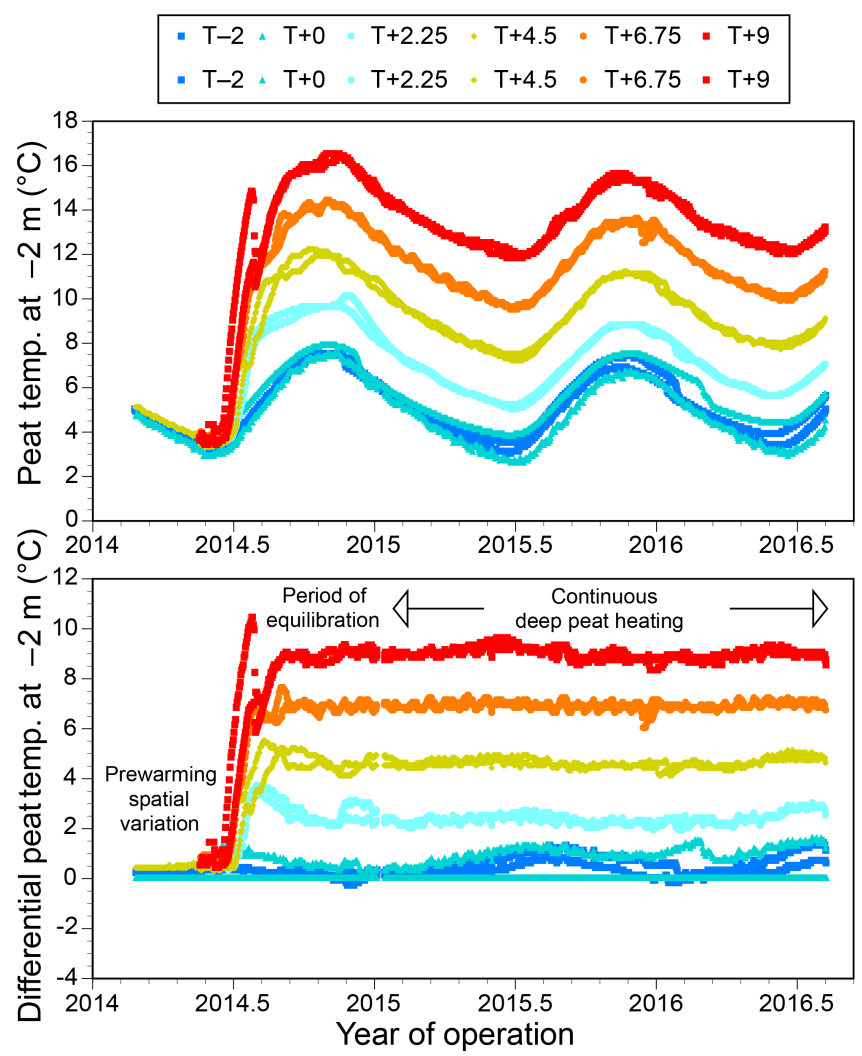

Figure 3. Daily mean deep peat temperatures (upper graph) and the associated temperature differentials (lower graph) at $-2 \mathrm{~m}$ by treatment plots since 2014 including the initial warm up periods (June through early September 2014), and the sustained application of deep peat heating with air warming (beginning September 2014). Differential temperatures are referenced to sensors within the fully constructed but no-energy-added control plot 6 . Unchambered ambient plot data are also shown as $T-2$ plots.

wave radiation at the surface within an enclosure is estimated by assuming that the enclosure walls emit blackbody radiation at a temperature equal to the simulated $2 \mathrm{~m}$ air temperature, and by using a sky view factor (defined as the proportion of the longwave radiation received by the surface within the enclosure that comes from the clear sky) of 0.3 to 0.35 . The sky view factor is assumed to be 1 outside the enclosure (neglecting the effects of the vegetation itself), while the inside values are calculated using the enclosure geometry. The enclosure walls are also assumed to cause a $20 \%$ reduction in incoming shortwave radiation. For these simulations, we do not consider the impacts of the enclosures on wind speed, precipitation or pressure. The effects of the enclosures on air and vegetation temperature, snow cover, dew formation and energy fluxes are simulated by the model and reported in the Discussion (Sect. 4).

\section{Results}

\subsection{Warming differentials}

WEW in the S1-Bog was achieved by warming air throughout the vertical profile of tall vegetation within an opentopped enclosure combined with belowground warming using low-wattage electrical resistance heaters optimized to the $12 \mathrm{~m}$ diameter space. Figure 3 demonstrates the effectiveness of the belowground heating method to produce a consistent deep-soil (peat) warming at $-2 \mathrm{~m}$ beginning in the summer of 2014. Peat is also warmed below $-2 \mathrm{~m}$, but continuous temperature monitoring below the $-2 \mathrm{~m}$ zone was not done. Differential deep-soil temperature targets were sustained following periods of gradual heat accumulation from 22 to 94 days for the cooler and warmest treatments, respectively (see Supplemental Table S3). Once deep-soil temperatures were achieved they were maintained consistently through time with the exception of a few minor power interruptions or during instrument maintenance periods. Deepsoil temperatures in unchambered ambient plots ( $\mathrm{T}-2$ lines in Fig. 3) were warmer than the designated reference control plot (plot 6). Variation in the no-energy-added controls (plot 6 vs. plot 19) represented spatial differences that were likely driven by variation in tree canopy cover. Greater canopy cover (plot 19) leading to warmer peat temperatures due to less heat loss to the sky.

Figure 4 shows consistent pretreatment seasonal air temperature patterns across plots prior to the full enclosure of the warming plots. Enclosure installations minus the bottom row of glazing were completed between mid-January and early April 2015. During the period from April through July 2015 air handling units and ductwork were installed. The bottom row of glazing was added in mid-August 2015 followed immediately by the initiation of constant stirring of the internal air space by the recirculating air handling furnaces. Air warming was initiated in all plots on 12 August 2015, and has been maintained near target levels since that time unless power outages or system maintenance needs interrupted operation (Fig. 4).

Unchambered ambient plots are commonly from 1 to $3{ }^{\circ} \mathrm{C}$ cooler than the fully constructed controls (Fig. 4), and plot to plot variation is responsible for the difference between our plot 6 reference control and plot 19 (the other no-energyadded control plot). The system based on PID control of $2 \mathrm{~m}$ air temperatures at the center of each enclosure is routinely capable of maintaining the differential temperatures for the +2.25 and +4.5 plots under virtually all environmental conditions. Currently, at higher winds $\left(>3 \mathrm{~m} \mathrm{~s}^{-1}\right)$ and for short periods of time the system occasionally falls below the +6.75 and $+9^{\circ} \mathrm{C}$ target temperatures (especially in the $+9^{\circ} \mathrm{C}$ plots 10 and 17). We continue to work on adjustments to the PID settings to minimize such issues, which are driven by the dilution of internal warm air by atypical cold air intrusions through the enclosures open top. 


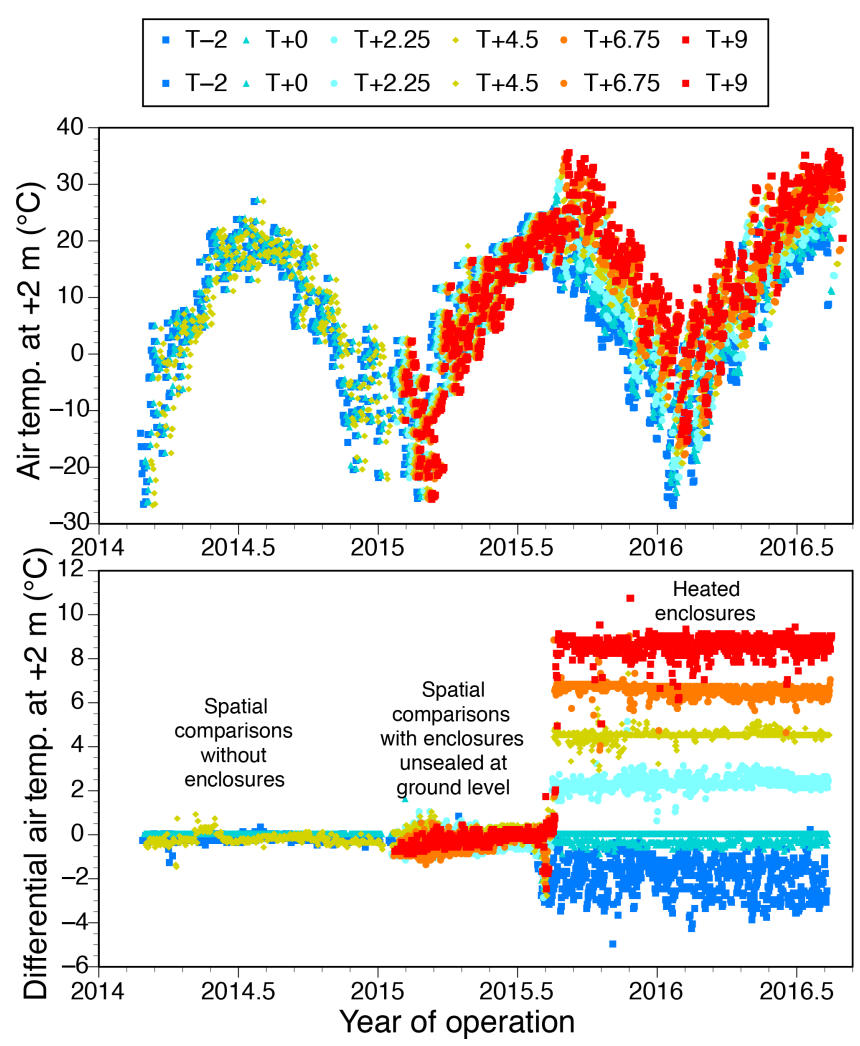

Figure 4. Daily mean air temperatures (upper graph) and the associated air temperature differentials at $+2 \mathrm{~m}$ above the bog surface (lower graph) by treatment plots since 2014, including periods prior to enclosure construction (through January 2015), a period when upper enclosures were in place (January to July 2015), and observations since full enclosure of each plot was achieved (27 July through 5 August 2015). Interior blower function was initiated at the time of full plot enclosure. The sustained period of warming began at 14:00 on 12 August 2015. Differential temperatures are referenced to sensors within the fully constructed but no-energy-added control plot 6. Unchambered ambient plot data are also shown as $T-2$ plots.

Since the initiation of DPH on 2 July 2014, belowground warming has been actively engaged greater than $98 \%$ of the time for all plots except plot 11 , which was operated $93 \%$ of the time (Table 1). Because the deep soils are largely selfinsulated, downtime for active DPH management resulted in only minor deviations from the target temperatures (Fig. 3). Active aboveground warming, initiated on 13 August 2015, has been maintained greater than $99 \%$ of the time in seven of eight plots and more than $96.5 \%$ of the time in plot 11 . When aboveground heating fails for any reason, differential heating is lost almost immediately adding air temperature variations greater than present in other plots that have not failed. Plot 11 downtime was the result of transect 2 power outages and winter issues with the air-warming heat exchangers (i.e., furnaces). Table 1 provides further details on the percentage of days in which the mean temperature was within $0.2,0.5,1$ or $1.5^{\circ} \mathrm{C}$ of the established targets for a given treatment plot.
Detailed plot-by-plot measured temperature data for both belowground and aboveground heating are available for viewing at the web portal http://sprucedata.ornl.gov, and are archived for detailed analysis in Hanson et al. (2016).

\subsection{Temperature profiles within the enclosures}

During the period of DPH, and continuing under WEW, DPH in the -1 to $-2 \mathrm{~m}$ peat depth was achieved (Fig. 3). During $\mathrm{DPH}$, air temperatures were not different, and surface peat temperatures did not achieve the full target warming temperatures due to heat losses to the atmosphere (Fig. 5a). With the addition of air warming, target temperature differentials were approximated from the tops of the enclosed trees to peat depths of at least $-2 \mathrm{~m}$ (Fig. 5b). The data in Fig. 5 are only single snapshots of these type of data, and some variation over time in the near-surface peat zone is expected due to rain and snow events that may temporarily upset local energy balance. The divergence of one peat temperature pattern in the B-series for one of the $+4.5^{\circ} \mathrm{C}$ temperature plots (Fig. 5b) resulted from proximal heating of that particular zone of soil by a heated air sampling tubing bundle. The heated bundle has since been repositioned to eliminate this local bias.

Horizontal air temperature patterns are minimal within the plots due to the stirring of the internal air by the fans of the air heating system and the coupling with external air exchanges (Fig. 2a). These phenomena are fully described in the description of the prototype enclosure published previously (Barbier et al., 2012), but color infrared temperatures provide quantitative data in support of the distribution of horizontal temperatures within the plots (Figs. 6 and S5).

\subsection{Temporal variation}

It is useful to understand how both short- (minute-by-minute) and longer-term (i.e., diurnal and seasonal) temporal variation within the enclosures compares between unchambered ambient and the chambered treatment plots. The following sections provide this comparison for sub-half-hour, diurnal and seasonal time periods.

\subsubsection{Sub-half-hour data}

Figure 7 shows that control plots compare well to unchambered ambient conditions with almost no change in the standard deviation metrics for minute-by-minute observations within half-hourly data. Conversely, the mean temperature standard deviations among $1 \mathrm{~min}$ data increase gradually with temperature treatments to nearly 2 times the nominal unchambered ambient standard deviation for the $+9^{\circ} \mathrm{C}$ treatment plots (Fig. 7 upper graph). Increased short-term variance results from temperature control inefficiencies. Subhalf-hour variance is greater, but not consistently so, with warming for the relative humidity data (Fig. 7 lower graph). 
Table 1. Statistics for time of operation and time within operational target temperature ranges for each treatment enclosure or plot. (a) Percent of time for active deep peat heating (DPH) and whole-ecosystem warming (WEW or air warming) since their respective inception in all treatment plots. (b) Percent of time belowground warming has been achieved since DPH targets were achieved in 2014. (c) Percent of time air warming has been achieved since August 2015. n/a is not applicable. All data are derived from daily mean air or soil temperature data.

\begin{tabular}{|c|c|c|c|c|c|}
\hline Treatment target temperature & $+0^{\circ} \mathrm{C}^{*}$ & $+2.25^{\circ} \mathrm{C}$ & $+4.5^{\circ} \mathrm{C}$ & $+6.75^{\circ} \mathrm{C}$ & $+9^{\circ} \mathrm{C}$ \\
\hline Plot no. & 19 & 20 & 13 & 16 & 10 \\
\hline
\end{tabular}

\begin{tabular}{lcrrrrrrrr}
\hline \multicolumn{1}{l}{ (a) Active temperature management } & & & & & & & \\
\hline
\end{tabular}

(c) WEW statistics $\%$ days within target ${ }^{\circ} \mathrm{C}$

\begin{tabular}{lrrrrrrrrr}
\hline Within $1.5^{\circ} \mathrm{C}$ & 99.5 & 95.6 & 99.5 & 98.7 & 97.4 & 91.7 & 98.7 & 93.9 & 95.2 \\
Within $1.0^{\circ} \mathrm{C}$ & 99.5 & 93.8 & 97.8 & 98.2 & 95.2 & 84.6 & 96.9 & 78.5 & 72.4 \\
Within $0.5^{\circ} \mathrm{C}$ & 51.3 & 91.2 & 85.1 & 89.5 & 71.9 & 57.0 & 67.5 & 46.1 & 37.3 \\
Within $0.2^{\circ} \mathrm{C}$ & 4.4 & 73.7 & 47.4 & 49.6 & 36.8 & 21.9 & 33.8 & 21.9 & 17.1 \\
\hline
\end{tabular}

\subsubsection{Diurnal data}

Diurnal data for the air temperature and relative humidity at $+2 \mathrm{~m}$ and soil temperature at $-2 \mathrm{~m}$ for control and treatment plots are illustrated in Fig. 8 for summer warm periods and in Fig. 9 for winter cold periods.

For both summer and winter conditions the SPRUCE system is capable of sustaining differential temperatures throughout diurnal cycles at the active control positions ( $+2 \mathrm{~m}$ above and $-2 \mathrm{~m}$ belowground) in a very consistent manner. Relative humidity, which is reduced with warming treatments (see also Table 4), also follows the diurnal patterns. Away from active control positions, it is important to point out that the stratification is similar, but not always maintained. For example, for soil temperatures at $-10 \mathrm{~cm}$ (Supplement Fig. S6), the treatments are largely maintained up through the soil profile (Fig. 5), but some differences develop driven by the unique energy balance relationships for a given SPRUCE enclosure. Such differences are driven by variable tree-cover conditions that effect local energy balance responsible for the development of soil profile temperature differentials above the $-2 \mathrm{~m}$ control depth.

Table 2 provides a quantitative assessment of the air temperature diurnal amplitudes. For unchambered ambient plots, diurnal amplitudes ranged from 13.7 to $14.1^{\circ} \mathrm{C}$ for warmseason periods and 8.5 to $8.9^{\circ} \mathrm{C}$ for cold-season periods. All treatment plot air temperature amplitudes remain within these diurnal ranges. Similarly, the unchambered ambient di- urnal range for $-2 \mathrm{~m}$ soil temperatures lies between 0 and $0.2^{\circ} \mathrm{C}$, which is matched in the treatment plots.

\subsubsection{Annual cycle data (2015 and 2016)}

The variation in air temperature, relative humidity and deepsoil temperature $(-2 \mathrm{~m})$ throughout an annual cycle for the 2015 and 2016 combined data are captured in frequency distribution plots of half-hourly data for each treatment (Fig. 10). The distributions show that the overall distribution of temperatures is largely retained under the warming scenarios, but warm plot relative humidity is constrained for the warmer treatments. No attempt to correct the change in the relative humidity frequency distribution was attempted because consistent guidance from climate models as to the exact nature of such distributions is not available for future climates.

Table 3 provides a quantitative assessment of annual amplitudes (approximated from summer maximums in 2015 and winter minimums in 2016) for air temperatures $\left(49\right.$ to $\left.51^{\circ} \mathrm{C}\right)$ and soil temperatures at $-2 \mathrm{~m}$ (DPH: 4 to $5^{\circ} \mathrm{C}$; WEW: 2.5 to $3.1^{\circ} \mathrm{C}$ ). The annual amplitudes are consistent among unchambered ambient and treatment plots (Table 3 ).

The SPRUCE experimental system is clearly capable of retaining the ambient variation across a wide temporal range with limited perturbation to the baseline cyclic patterns. 
Table 2. Range of diurnal air temperature amplitudes (AT, ${ }^{\circ} \mathrm{C}$ ) at $+2 \mathrm{~m}$ in warm (DOY 230 to 300 ) and cold (DOY 300 to 365 ; 1 to 13 ) seasons, and the mean diurnal soil temperature amplitude $\left(\mathrm{ST},{ }^{\circ} \mathrm{C}\right)$ at $-2 \mathrm{~m}$ for a period including the warmest and coldest extremes of the measurement period (August 2015-January 2016).

\begin{tabular}{lrrrrrr}
\hline Treatment and plots & $\begin{array}{r}\text { Ambient plots } \\
(7,21)\end{array}$ & $\begin{array}{r}+0{ }^{\circ} \mathrm{C} \text { plots } \\
(6,19)\end{array}$ & $\begin{array}{r}+2.25^{\circ} \mathrm{C} \text { plots } \\
(11,20)\end{array}$ & $\begin{array}{r}+4.5^{\circ} \mathrm{C} \text { plots } \\
(4,13)\end{array}$ & $\begin{array}{r}+6.75^{\circ} \mathrm{C} \text { plots } \\
(8,16)\end{array}$ & $\begin{array}{r}+9{ }^{\circ} \mathrm{C} \text { plots } \\
(10,17)\end{array}$ \\
\hline Warm-season AT diurnal amplitude & $13.7-14.1$ & $14.0-14.1$ & $13.0-13.7$ & $13.3-13.5$ & $13.9-14.2$ & $13.2-13.6$ \\
Cold-season AT diurnal amplitude & $8.5-8.9$ & $8.1-8.4$ & $7.9-8.3$ & $8.3-8.4$ & $8.5-8.8$ & $8.8-8.9$ \\
$-2 \mathrm{~m}$ soil temperate diurnal amplitude & $0.0-0.2$ & $0.0-0.3$ & 0.0 & $0.1-0.1$ & $0.1-0.1$ & $0.0-0.1$ \\
\hline
\end{tabular}

Table 3. Annual range of observed maximum minus minimum air temperature at $+2 \mathrm{~m}\left(\mathrm{AT},{ }^{\circ} \mathrm{C}\right)$ for the whole-ecosystem-warming $(\mathrm{WEW})$ period from August 2015 through January 2016, which includes the warmest and coldest periods of an annual cycle. Also shown is the range of maximum minus minimum soil temperatures (ST) at $-2 \mathrm{~m}$ throughout the deep peat heating period in 2014 and 2015 , and the WEW period since August 2015.

\begin{tabular}{|c|c|c|c|c|c|c|}
\hline Treatment and plots & $\begin{array}{r}\text { Ambient plots } \\
(7,21)\end{array}$ & $\begin{array}{r}+0{ }^{\circ} \mathrm{C} \text { plots } \\
(6,19)\end{array}$ & $\begin{array}{r}+2.25^{\circ} \mathrm{C} \text { plots } \\
(11,20)\end{array}$ & $\begin{array}{r}+4.5^{\circ} \mathrm{C} \text { plots } \\
(4,13)\end{array}$ & $\begin{array}{r}+6.75^{\circ} \mathrm{C} \text { plots } \\
(8,16)\end{array}$ & $\begin{array}{r}+9^{\circ} \mathrm{C} \text { plots } \\
(10,17)\end{array}$ \\
\hline$+2 \mathrm{~m}$ AT for WEW & $50.4-51.1$ & $50.2-50.5$ & 50.5 & $50.2-50.5$ & $50.6-50.8$ & $49.1-50.5$ \\
\hline$-2 \mathrm{~m} \mathrm{ST}$ annual amplitude for DPH & $4.0-4.4$ & $4.0-4.9$ & $4.5-5.1$ & $4.9-4.9$ & $4.9-5.0$ & $4.6-4.9$ \\
\hline$-2 \mathrm{~m}$ ST annual amplitude for WEW & $2.4-2.5$ & $2.6-3.1$ & $2.6-2.8$ & $2.9-2.9$ & $3.0-3.0$ & $2.6-2.9$ \\
\hline
\end{tabular}

\subsection{Unchambered ambient vs. enclosure environments}

The mild belowground warming applied in SPRUCE produces minimal artifacts due to the deep-soil target warming location and the low-wattage-heater application of energy. In contrast, the construction of walled enclosures to make air warming tenable produces a number of changes from ambient conditions that need to be considered including light, wind, humidity, precipitation, dew formation, and snow and ice accumulation.

Light levels within the plots before and after the installation of enclosures are plotted for selected plots in Fig. 11. With the installation of the enclosure aluminum structure and the addition of double-walled greenhouse glazing, midday PAR levels within the enclosures are reduced by about $20 \%$. Under cloudy conditions, or in the morning and evening when a greater fraction of the light is diffuse, these differences are smaller. The greenhouse panels were not UV transparent, but forest vegetation is known to largely tolerate UV light (Qi et al., 2010).

Shortwave and longwave incident radiation data for the SPRUCE enclosures are reduced and enhanced, respectively, when compared directly to matched data for unchambered ambient conditions. Figure 12 shows examples of such data for a north and south centered location within plot 6 in the summer of 2016. When averaged over multiple midsummer days the mean daily reduction of incident shortwave radiation was $24.2 \pm 2.4 \%$ at north plot locations and $40.9 \pm 3.7 \%$ for fully impacted southern locations (i.e., area of the plot subjected to all frustum, glazing and wall frame influences). Opposite the effect for shortwave radiation, increases in longwave radiation incident on the surface showed a mean daily increase of $10 \pm 2 \%$, but increases were greater in the daytime than for nighttime conditions (Fig. 12).

Ground level winds within the enclosures were necessarily enhanced to distribute heated air from the edge sources to the center of the plot (Fig. 2a). To account for this enhanced wind effect, the fully constructed control applies the same air-blowing system. While this provides a difference between ambient conditions and treatment plots, it is fully controlled and comparable across all heated enclosures. The air dynamics induced by external winds entering each enclosure through the open top combined with internal turbulence generated by the blowers homogenizes the air volume inside the enclosure. Figure 13 shows a time series of vertical wind velocity and average horizontal wind speed data contrasting unchambered ambient plots (plots 2 and 21) with an unheated enclosure (plot 6) and the two $+9{ }^{\circ} \mathrm{C}$ enclosures (plots 10 and 17). There is more turbulence in the enclosures than in ambient air and the turbulence increases with the level of warming. Horizontal wind speeds are diurnally variable and comparable in both enclosed and unchambered ambient plots. Vertical wind speeds are greater in the warming enclosures, increase with level of warming and are always in the upwards direction both day and night.

Within the WEW enclosure total air turnover rates vary with external winds, and have been measured using the dilution of constant $\mathrm{CO}_{2}$ additions. At external wind velocities less than $0.5 \mathrm{~m} \mathrm{~s}^{-1}$ the enclosure air turns over approximately 1 time every $5 \mathrm{~min}$. As winds approach $8 \mathrm{~m} \mathrm{~s}^{-1}$, the total air volume is turned over once per minute.

Absolute humidity within the enclosures is conserved across treatments (Fig. S7). This is possible because of the wind-induced turnover of air within the enclosures. Con- 
Table 4. Plot-to-plot variation in mean daily relative humidity $\pm \mathrm{SD}(\mathrm{RH} ; \%)$ at $+2 \mathrm{~m}$ before the construction of enclosures (a), with enclosures (b), with active air-warming treatments engaged during warm periods (c) and with heating during winter (d).

\begin{tabular}{|c|c|c|c|c|c|c|}
\hline & $\begin{array}{r}\text { Ambient plots }(7,21) \\
(7,21)\end{array}$ & $\begin{array}{r}+0^{\circ} \mathrm{C} \text { plots } \\
(6,19)\end{array}$ & $\begin{array}{r}+2.25^{\circ} \mathrm{C} \text { plots } \\
(11,20)\end{array}$ & $\begin{array}{r}+4.5^{\circ} \mathrm{C} \text { plots } \\
(4,13)\end{array}$ & $\begin{array}{r}+6.75^{\circ} \mathrm{C} \text { plots } \\
(8,16)\end{array}$ & $\begin{array}{r}+9^{\circ} \mathrm{C} \text { plots } \\
(10,17)\end{array}$ \\
\hline \multicolumn{7}{|l|}{ (a) Before ${ }^{a}$} \\
\hline Max RH & $99.0 \pm 0.2$ & $98.8 \pm 0.0$ & NA & $99.0 \pm 0.1$ & NA & NA \\
\hline Mean RH & $79.7 \pm 0.3$ & $82.5 \pm 0.2$ & NA & $79.3 \pm 0.1$ & NA & NA \\
\hline Min RH & $52.3 \pm 0.4$ & $57.9 \pm 0.2$ & NA & $52.6 \pm 0.0$ & NA & NA \\
\hline \multicolumn{7}{|c|}{ (b) With enclosures ${ }^{\mathrm{b}}$} \\
\hline Max RH & $99.6 \pm 0.1$ & $99.7 \pm 0.1$ & $99.2 \pm 0.3$ & $99.7 \pm 0.1$ & $99.5 \pm 0.2$ & $99.4 \pm 0.4$ \\
\hline Mean RH & $77.4 \pm 0.7$ & $77.9 \pm 0.6$ & $76.9 \pm 0.3$ & $77.6 \pm 0.5$ & $77.1 \pm 0.6$ & $76.8 \pm 0.7$ \\
\hline Min RH & $48.7 \pm 0.9$ & $50.1 \pm 0.5$ & $49.2 \pm 0.3$ & $49.7 \pm 0.6$ & $49.4 \pm 0.4$ & $48.9 \pm 0.2$ \\
\hline \multicolumn{7}{|c|}{ (c) With heating ${ }^{\mathrm{c}}$} \\
\hline Max RH & $99.4 \pm 0.3$ & $96.7 \pm 0.5$ & $83.8 \pm 1.8$ & $76.7 \pm 2.4$ & $66.0 \pm 0.5$ & $58.8 \pm 0.7$ \\
\hline Mean RH & $81.8 \pm 1.0$ & $78.1 \pm 0.2$ & $66.3 \pm 1.5$ & $60.1 \pm 1.8$ & $51.1 \pm 0.1$ & $45.1 \pm 0.5$ \\
\hline Min RH & $54.5 \pm 0.9$ & $51.9 \pm 0.1$ & $44.7 \pm 1.0$ & $40.6 \pm 1.2$ & $33.7 \pm 0.5$ & $30.4 \pm 0.6$ \\
\hline \multicolumn{7}{|c|}{ (d) Winter heating ${ }^{\mathrm{d}}$} \\
\hline Max RH & $95.7 \pm 0.4$ & $92.6 \pm 0.7$ & $77.6 \pm 1.0$ & $68.6 \pm 1.4$ & $59.6 \pm 1.2$ & $53.0 \pm 1.6$ \\
\hline Mean RH & $89.2 \pm 0.6$ & $85.7 \pm 0.4$ & $70.2 \pm 0.9$ & $61.1 \pm 1.1$ & $53.0 \pm 0.9$ & $46.8 \pm 2.9$ \\
\hline Min RH & $77.0 \pm 0.4$ & $73.1 \pm 0.3$ & $58.8 \pm 0.6$ & $50.0 \pm 0.5$ & $43.9 \pm 0.7$ & $39.3 \pm 4.1$ \\
\hline
\end{tabular}

${ }^{a}$ Days compared are days of the year 160 to 200 in $2014 .{ }^{b}$ Days compared are days of the year 160 to 200 in $2015 .{ }^{c}$ Days compared are days of the year 230 to 300 in 2015. ${ }^{\mathrm{d}}$ Days compared are days of the year 335 in 2015 to 10 in 2016. NA is not available.

versely, relative humidity (Table 4) varies by treatment. The environment within the fully constructed controls closely matches ambient relative humidity, but relative humidity within the warmed plots drops proportionate to the warming treatments being only 51 to $55 \%$ of the control for the most extreme warming treatment $\left(+9^{\circ} \mathrm{C}\right.$; Table 4$)$.

Although common in ambient settings, dew formation has not been observed in any of the warmed treatment enclosures, as relative humidity never reaches $100 \%$. While this was to be expected for the warmed plots, we were not certain if dew would form in the no-energy-added control enclosures. In the control plots, relative humidity $(\mathrm{RH})$ does reach $100 \%$ on occasion, which would indicate some dew formation. Even so, the foliage in the control plots has not been visibly wet in the mornings, in stark contrast to the often heavy dew formation on foliage in unchambered ambient plots.

Apparent water content and rate of soil drying also varies across plots due to the heterogeneous density of hollows and differential tree density. Even so, the rate of soil drying increased when the plot heating began, and drying was positively correlated with increasing plot temperatures indicating enhanced evapotranspirational demand (J. Warren, personal communication, 2016).

\subsection{Snow and ice accumulation}

An area of uncertainty in the development of the WEW prototypes in eastern Tennessee (Barbier et al., 2012) was how snow accumulation would develop within the plots when deployed in Minnesota. Observations throughout the winter of 2015-2016 showed that snow actively accumulates within the enclosures with a more or less uniform distribution around the plots (Fig. S8). Ground level blower effects are limited to the edges of the plots (data not shown). Active snow enters all warmed treatment plots, but its accumulation as a snow layer depends on the temperatures of the vegetation and peat surface. Snow has been seen to accumulate in all warmed plots if overall conditions allow, but it thaws or sublimates much faster in the warmed plots. The control enclosures did not accumulate as much snow as ambient locations, but ice accumulation within the peat profile was equal to or greater than the accumulation in ambient areas at times (Fig. 14). During the spring of 2016 the warmed plots lost their snow cover and ice thawed faster than in the colder plots consistent with expectations for the experimental design.

\subsection{Energy use}

The in situ WEW facility for tall-stature plants was expensive to build yet cost effective to operate given the nature of the treatments. Key daily energy requirements for each 
(a) Deep peat heating profile

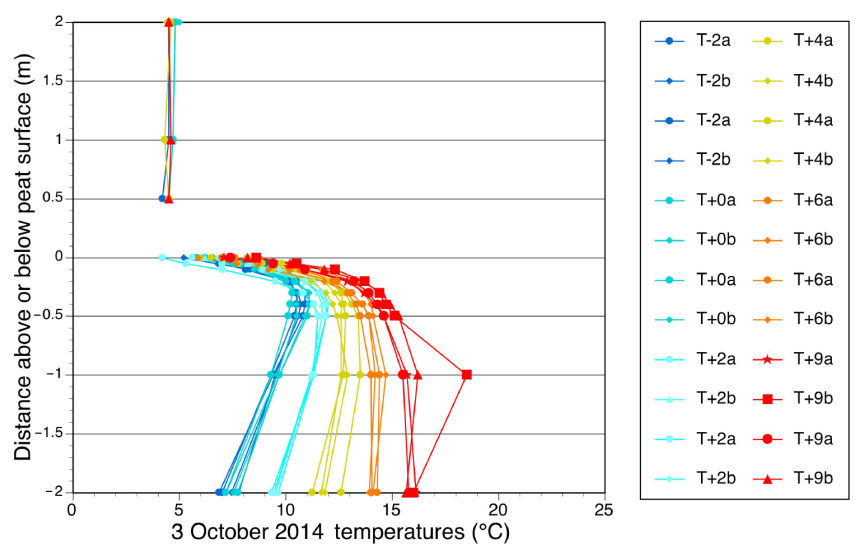

(b) Whole ecosystem warming profile

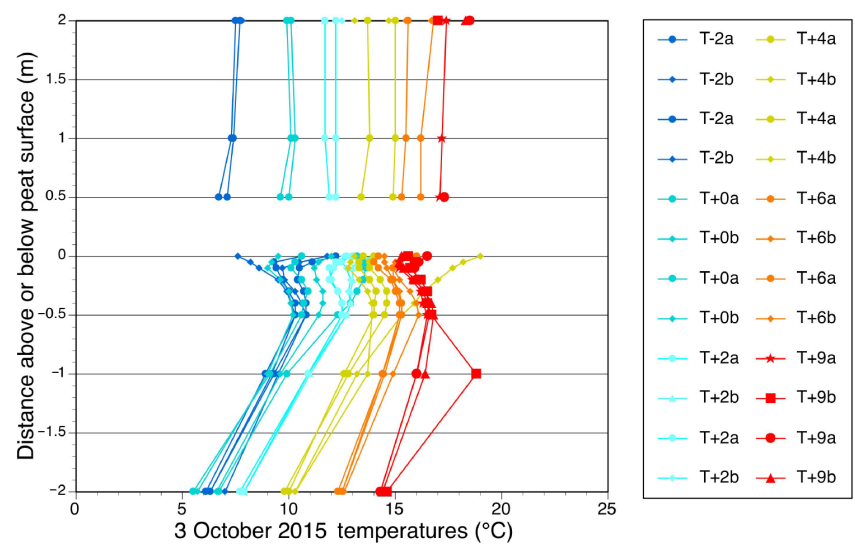

Figure 5. Temperature profiles from $+2 \mathrm{~m}$ above through $-2 \mathrm{~m}$ below the peat bog hollow surface for (a) 3 October 2014 during deep peat heating and (b) 3 October 2015 under whole-ecosystem warming. Air temperatures are the daily mean and soil temperatures are the value recorded at noon. Colors in the figure legend show data for unchambered ambient $(T-2 x)$, no-energy-added control $(T+0 x)$ and warmed plots: $+2.25(T+2 x),+4.5(T+4 x),+6.75(T+6 x)$ and $+9(T+9 x){ }^{\circ} \mathrm{C}$, where $x$ is either the $a$ or the $b$ series temperature zone within the plots.

treatment plot under warm and cold-season conditions are presented in Table 5. Soil warming using resistance heating was continuously measured in amps converted to $\mathrm{kW} \mathrm{h}$. Air warming using LPG for the full experimental site was estimated for each treatment in gallons of LPG. Both energy units were converted to mega Joules (MJ) to make direct comparisons among the warming methods. Air warming required 88 to $89 \%$ of the energy for WEW ranging from $64283 \mathrm{MJ} \mathrm{d}^{-1}$ during the warm season to $80102 \mathrm{MJ} \mathrm{d}^{-1}$ during cold months. Soil warming required only 1.3 to $1.9 \%$ of the energy used ranging from 954 to $1782 \mathrm{MJ} \mathrm{d}^{-1}$ of energy in the warm and cold seasons, respectively. Although not a direct energy requirement for warming, 9 to $11 \%$ of the energy used was needed to drive the forced-air blowers necessary to distributed warm air across the $12 \mathrm{~m}$ diameter enclosures.

\subsection{Elevated $\mathrm{CO}_{2}$ treatments}

The capacity for adding pure $\mathrm{CO}_{2}$ of known isotopic signature (obtained from an ammonia production plant) to the air handling units of an enclosure to increase the atmospheric $\left[\mathrm{CO}_{2}\right]$ is demonstrated in Fig. 15. Based on 6 min running mean observations, we have sustained a $+500 \mathrm{ppm}$ treatment within $\pm 100 \mathrm{ppm}$ using the current algorithms for a wide range of external wind speeds (Fig. 15).

We are continuing to look at our control methods and will attempt to reduce the variation around the target differentials. A comparison of these $\mathrm{eCO}_{2}$ data with plot-to-plot variation for the non-eCO $\mathrm{CO}_{2}$ enclosures (Supplement Table S5) suggests that the variation stems in part from spatial variation hypothesized to be driven by localized differential air exchange between outside air and the large enclosure volume. Warming and the buoyancy that it induces can also confound our capacity to achieve a consistent $+500 \mathrm{ppm} \mathrm{eCO}$ treatment. The mean isotopic signature of the elevated air was measured during the summer of 2016 as $-22.6 \% \circ \partial^{13} \mathrm{C}$ and -517 to $-564 \% \Delta^{14} \mathrm{C}$.

\section{Discussion}

Although there has been considerable discussion of the utility and merits of various warming methods in recent years (Aronson and McNulty, 2009; Amthor et al., 2010; Kimball, 2011), we chose to use air warming and deep-soil warming for our studies, and have found the method appropriate for warming a tall-stature ecosystem ( 3 to $7 \mathrm{~m}$ ) with active root and microbial populations $(>-2 \mathrm{~m})$. The SPRUCE WEW enclosures provide us with the means to glimpse warming futures at scales appropriate for the evaluation of peatland vegetation, microorganisms and ecosystem functions. The SPRUCE enclosures are able to maintain the full range of warming treatments $\left(+2.25,+4.5,+6.75\right.$ and $\left.+9{ }^{\circ} \mathrm{C}\right)$ over external wind velocities ranging from 0 to as much as $6 \mathrm{~m} \mathrm{~s}^{-1}$. The system allowed for the application of the warming treatments largely uninterrupted throughout a full annual cycle. The experimental systems were successfully installed in a sensitive wetland ecosystem with minimal visible impact on the target plot vegetation and underlying peat column. The warming treatments provide a reasonable approximation of projected future climate and atmospheric boundary conditions within which to study a full range of vegetation, microbial and biogeochemical cycling responses.

Spatial variation was an important consideration during the development of the belowground and air-warming protocols during construction and testing of the full-size prototype in Oak Ridge, Tennessee (Barbier et al., 2012). Within 

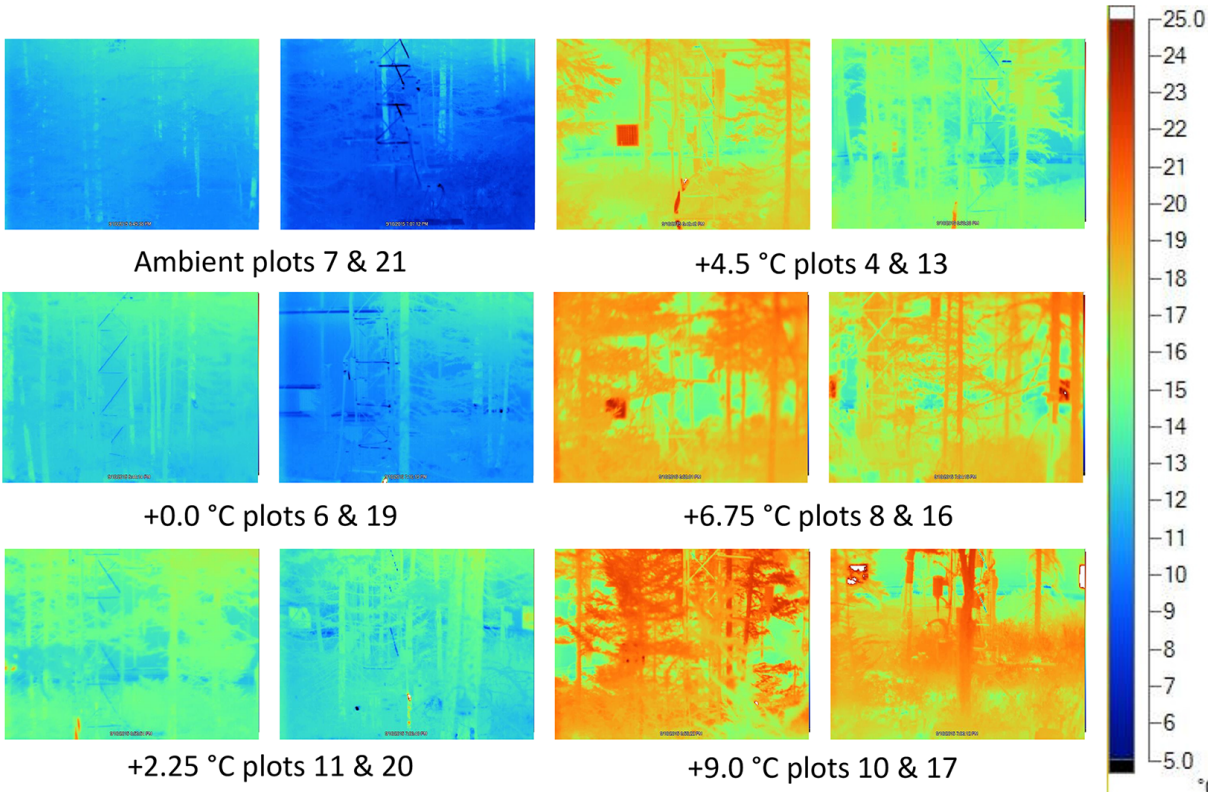

$+0.0^{\circ} \mathrm{C}$ plots $6 \& 19$

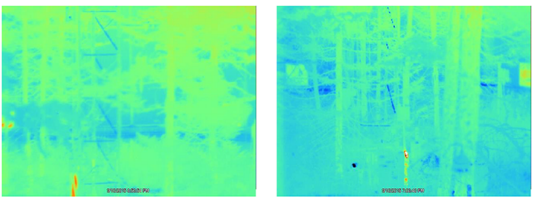

$+2.25^{\circ} \mathrm{C}$ plots $11 \& 20$

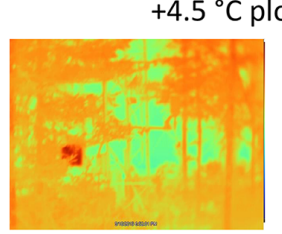

ots $4 \& 13$

$+6.75^{\circ} \mathrm{C}$ plots $8 \& 16$
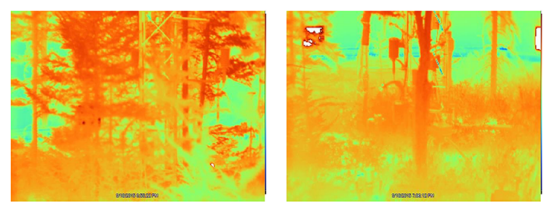

$+9.0^{\circ} \mathrm{C}$ plots $10 \& 17$

Figure 6. Color infrared images for the space within the designated treatment enclosures taken on 10 September 2015 after sunset within a $30 \mathrm{~min}$ period. The thermal color scale in ${ }^{\circ} \mathrm{C}$ applies to all images. Non-biological metal or plastic surfaces in the images may not provide an accurate temperature due to their emissivity difference from biological surfaces.

Table 5. Daily energy requirements for air and soil warming for the overall experiment and values for individual treatment plots.

\begin{tabular}{|c|c|c|c|c|c|c|}
\hline \multirow{2}{*}{$\begin{array}{l}\text { Season } \\
\text { Treatment energy use }\end{array}$} & \multicolumn{3}{|c|}{$\begin{array}{l}\text { Warm-season months } \\
\text { (April to October) }\end{array}$} & \multicolumn{3}{|c|}{$\begin{array}{c}\text { Winter months } \\
\text { (November to March) }\end{array}$} \\
\hline & $\mathrm{kWh} \mathrm{d}^{-1}$ & Gallons LPG d ${ }^{-1}$ & $\mathrm{~d}^{-1}$ & $\mathrm{~kW} \mathrm{~h} \mathrm{~d}^{-1}$ & Gallons LPG d ${ }^{-1}$ & $\mathrm{MJ} \mathrm{d}^{-1}$ \\
\hline \multicolumn{7}{|l|}{ Air warming $^{a}$} \\
\hline Full experiment & - & 638 & 64283 & - & 795 & 80102 \\
\hline \multicolumn{7}{|l|}{ By treatment $\mathrm{t}^{\mathrm{b}}$} \\
\hline$+0{ }^{\circ} \mathrm{C}$ enclosure & - & 0 & 0 & - & 0 & 0 \\
\hline$+2.25^{\circ} \mathrm{C}$ enclosure & - & $\sim 31.9$ & $\sim 3214$ & - & $\sim 39.7$ & $\sim 4000$ \\
\hline$+4.5^{\circ} \mathrm{C}$ enclosure & - & $\sim 63.8$ & $\sim 6428$ & - & $\sim 79.5$ & $\sim 8010$ \\
\hline$+6.75^{\circ} \mathrm{C}$ enclosure & - & $\sim 95.7$ & $\sim 9642$ & - & $\sim 119.25$ & $\sim 12015$ \\
\hline$+9^{\circ} \mathrm{C}$ enclosure & - & $\sim 127.6$ & $\sim 12857$ & - & $\sim 159$ & $\sim 16020$ \\
\hline \multicolumn{7}{|l|}{ Soil warming ${ }^{\mathrm{c}}$} \\
\hline Full experiment & 265 & - & 954 & 495 & - & 1782 \\
\hline \multicolumn{7}{|l|}{ By treatment } \\
\hline$+0^{\circ} \mathrm{C}$ enclosure & 0 & - & 0 & 0 & - & 0 \\
\hline$+2.25^{\circ} \mathrm{C}$ enclosure & $9.0 \pm 1.7$ & - & $32.4 \pm 6.1$ & $12.6 \pm 0.8$ & - & $45.4 \pm 3.0$ \\
\hline$+4.5^{\circ} \mathrm{C}$ enclosure & $24.6 \pm 0.3$ & - & $88.6 \pm 1.0$ & $31.9 \pm 2.9$ & - & $115.0 \pm 10.4$ \\
\hline$+6.75^{\circ} \mathrm{C}$ enclosure & $38.8 \pm 7.1$ & - & $139.7 \pm 25.5$ & $46.7 \pm 11.0$ & - & $168.3 \pm 39.5$ \\
\hline$+9{ }^{\circ} \mathrm{C}$ enclosure & $62.2 \pm 27.3$ & - & $223.9 \pm 98.2$ & $69.4 \pm 21.2$ & - & $249.8 \pm 76.4$ \\
\hline Blower energy ${ }^{d}$ & $\sim 2222$ & - & 7999 & $\sim 2276$ & - & 8194 \\
\hline
\end{tabular}



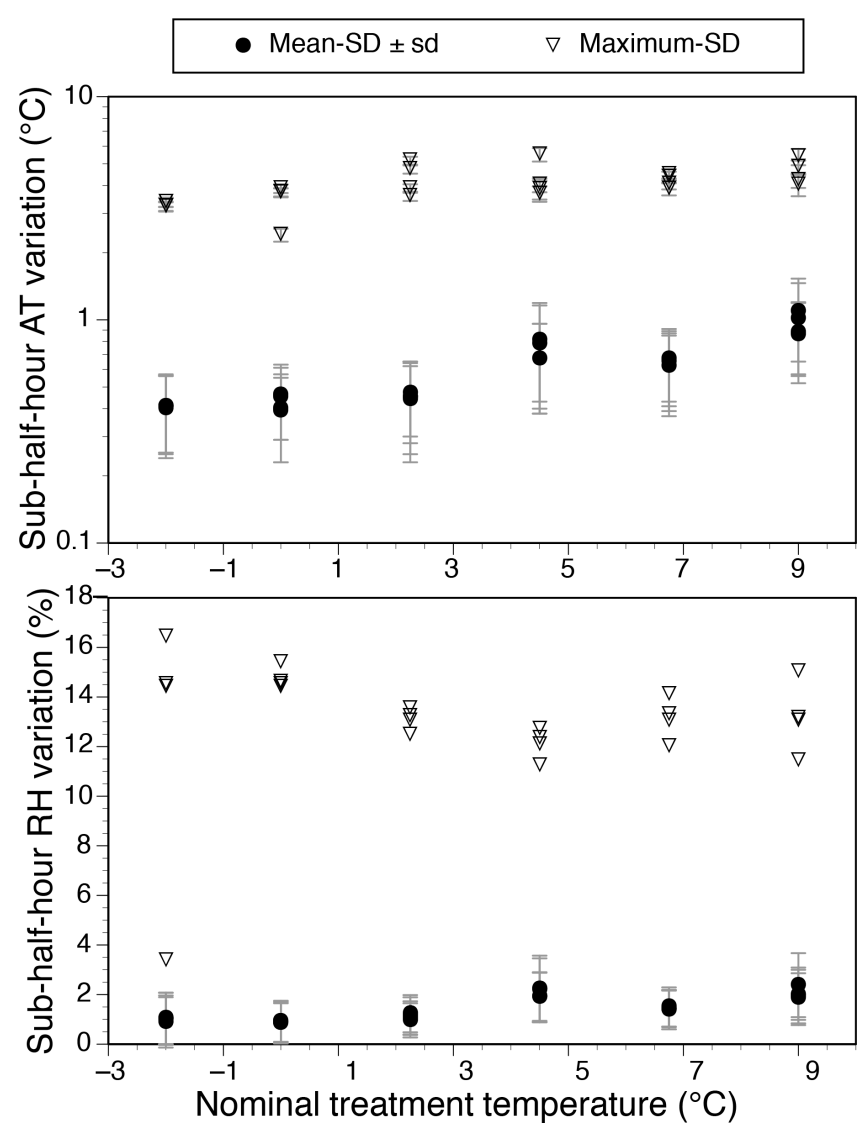

Figure 7. Sub-half-hour variation of air temperature (upper graph) and relative humidity (lower graph) data expressed as the standard deviation (SD or sd) of 1 min observations within a half-hourly measurement period. Plotted data are the mean $\mathrm{SD} \pm \mathrm{sd}$ and maximum SD for half-hourly temperature and relative humidity data over the whole-ecosystem-warming period of observations reported in this paper for two replicate sensors in each treatment enclosure or plot. The -2 and $0{ }^{\circ} \mathrm{C}$ treatments in this graph represent unchambered ambient and no-energy-added control enclosures respectively.

the prototype system, a 3-D-monitoring approach included a central tower and spaced sensors located at various heights and distances from the center of the plot. They were established and monitored to capture spatial details. During prototype development, we also monitored soil temperatures to $-2 \mathrm{~m}$ along a radius from edge to center of the plot in that prototype. Results from the Barbier et al. (2012) paper demonstrated little spatial variation belowground, and some variable aboveground spatial homogeneity driven by external wind velocities. The greatest variation in the warm air envelope aboveground occurred under calm conditions, and a full discussion of spatial considerations is included in Barbier et al. (2012).

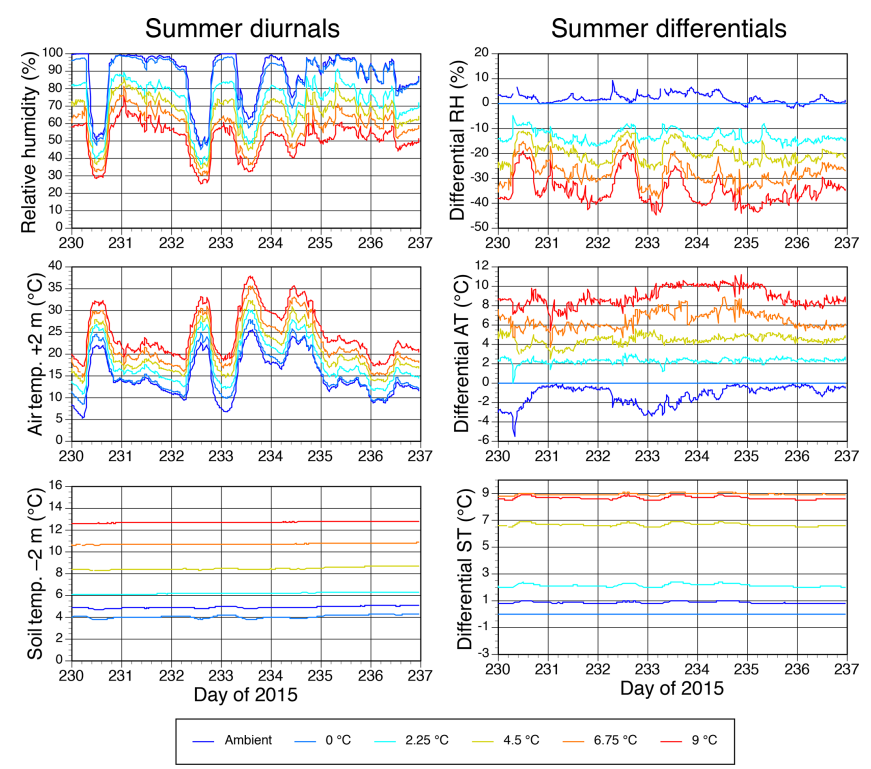

Figure 8. A warm-season, 7-day example of the diurnal variations in air temperature and relative humidity at $+2 \mathrm{~m}$, and soil temperatures at the reference depth of $-2 \mathrm{~m}$. Calculated differentials with respect to reference plot 6 are provided in the right-hand column.
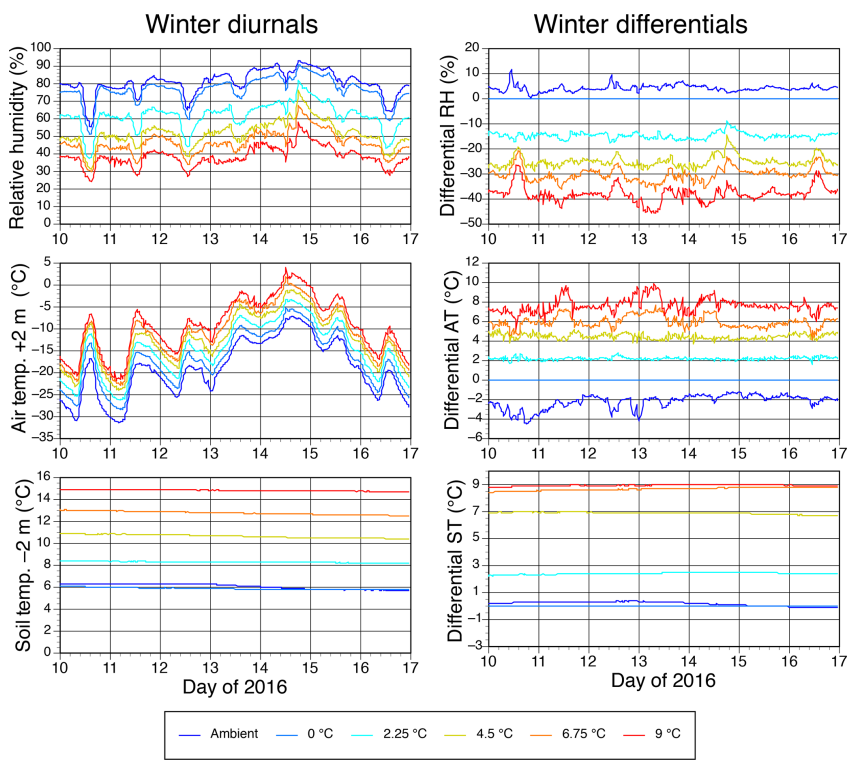

Figure 9. A cold-season, 7-day example of the diurnal variations in air temperature and relative humidity at $+2 \mathrm{~m}$, and soil temperatures at the reference depth of $-2 \mathrm{~m}$. Calculated differentials with respect to reference plot 6 are provided in the right-hand column.

\subsection{Comparing WEW to other methods}

Other notable studies using either air warming or direct surface warming via infrared lamps have also been deployed to understand warming responses for a range of ecosystems (Table 6; Aronson and McNulty, 2009; LeCain et al., 


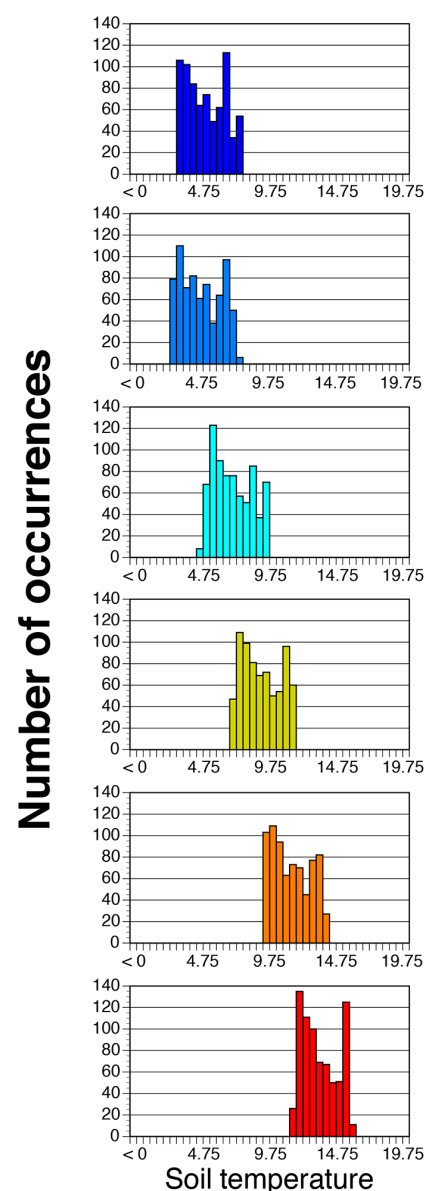

$\left({ }^{\circ} \mathrm{C}\right)$
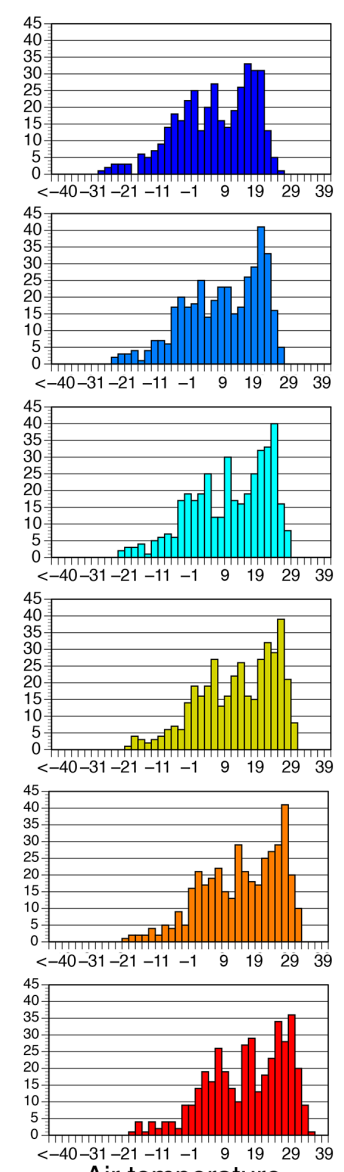

Air temperature

$\left({ }^{\circ} \mathrm{C}\right)$

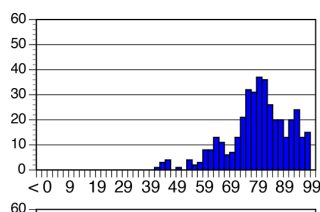

Ambient

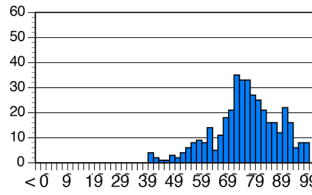

$<099192939495969798999$
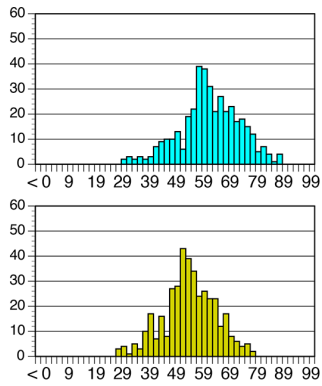

$<09192939495969798999$

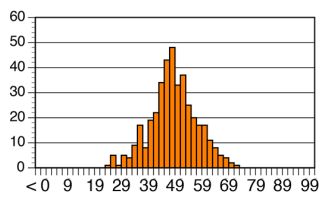

$+6.75^{\circ} \mathrm{C}$

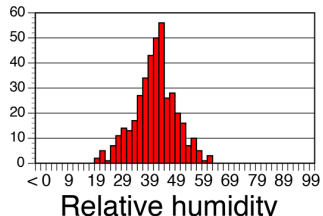

Relative humidity

$(\%)$

Figure 10. Frequency distributions for daily mean soil temperature at $-2 \mathrm{~m}$ (left column), air temperature at $+2 \mathrm{~m}$ (middle column) and daily mean relative humidity at $+2 \mathrm{~m}$ (right column) throughout the evaluation period in 2015 and 2016. Data in the frequency distribution for soil temperature include the period from September 2014 to September 2016, which includes the deep peat heating period. Data in the frequency distributions for air temperature and relative humidity include data from August 2015 to September 2016.

2015; Rustad et al., 2001). Air-warming methods for field applications were established by Norby et al. (1997) for application to tree seedling and old-field research. They achieved air warming of $+3^{\circ} \mathrm{C}$ within $7.1 \mathrm{~m}^{2}$ plots with limited soil warming through air to soil heat transfer. Bronson et al. $(2008,2009)$ built larger air-warming chambers $\left(41.8 \mathrm{~m}^{2}\right)$ combined with soil-warming cables to study an upland Picea mariana plantation at +1.8 and $+3.5^{\circ} \mathrm{C}$ air warming and partial soil warming (i.e., near surface).

Infrared lamp-warming studies have also been successfully used to study warming effects for some time (Harte et al., 1995), and most recent field-scale infrared lamp studies have employed designs based on Kimball et al. (2008). Notable for comparison to the SPRUCE peatland work was the study by Bridgham et al. (1999), which used constant output infrared lamps to generate seasonally realistic warming from +1.6 to $+4.1^{\circ} \mathrm{C}$ in extracted peat monoliths. More recently and for in situ work in prairie systems, LeCain et al. (2015) deployed infrared lamps over hydraulically iso- lated plots achieving variable day/night canopy warming of $+1.5 /+3.0^{\circ} \mathrm{C}$, respectively, and surface soil warming at $3 \mathrm{~cm}$ depth up to $3.8^{\circ} \mathrm{C}$. Rich et al. (2015) described a warming study targeting temperate seedling responses in an upland forest with a system using infrared lamps and buried cables over trenched plots to warm vegetation canopy surfaces to +1.8 and $+3.5^{\circ} \mathrm{C}$. They reported significant warming within the soil profile, but did not achieve full deepsoil warming consistent with their aboveground temperature treatments. Notwithstanding the lack of deep-soil warming and unassessed air warming, the Rich et al. (2015) study is very impressive encompassing two sites and a total of 72 treatment plots deployed in a factorial design. Infrared heating designs for much larger plots than those used by these groups have also been proposed (Kimball et al., 2011), and one such study is currently underway in a Puerto Rico tropical forest understory using $4 \mathrm{~m}$ diameter plots (T. Wood, personal communication, 2016; Cavaleri et al., 2015). Where vegetation canopies are short in stature and therefore receive 
Table 6. Comparison of the SPRUCE WEW system characteristics to other representative plot-scale-warming approaches operated in field settings. Data are summarized at the individual plot level. Other warming studies not covered in this table are summarized by Rich et al. (2015), Aronson and McNulty (2009), LeCain et al. (2015) and Rustad et al. (2001).

\begin{tabular}{|c|c|c|c|c|c|c|}
\hline Study/PI & $\begin{array}{l}\text { SPRUCE WEW } \\
\text { this study }\end{array}$ & $\begin{array}{l}\text { Black spruce planta- } \\
\text { tion } \\
\text { Bronson et al. (2008, } \\
2009 \text { ) }\end{array}$ & $\begin{array}{l}\text { B4Warmed } \\
\text { Rich et al. (2015) }\end{array}$ & $\begin{array}{l}\text { PHACE } \\
\text { LeCain et al. (2015) }\end{array}$ & $\begin{array}{l}\text { Peatland } \\
\text { Bridgham } \\
\text { et al. (1999) }\end{array}$ & $\begin{array}{l}\text { temperate } \\
\text { seedlings } \\
\text { Norby et al. (1997) }\end{array}$ \\
\hline $\begin{array}{l}\text { Lat./long. } \\
\text { (degrees) }\end{array}$ & $\begin{array}{l}47.508^{\circ} \mathrm{N} \\
-93.453^{\circ} \mathrm{W}\end{array}$ & $\begin{array}{l}55.883^{\circ} \mathrm{N} \\
-98.333^{\circ} \mathrm{W}\end{array}$ & $\begin{array}{l}46.679^{\circ} \mathrm{N} \\
-92.520^{\circ} \mathrm{W} \\
\& \\
47.946^{\circ} \mathrm{N} \\
-91.758^{\circ} \mathrm{W}\end{array}$ & $\begin{array}{l}41.183^{\circ} \mathrm{N} ; \\
-104.900^{\circ} \mathrm{W}\end{array}$ & $\begin{array}{l}47^{\circ} \mathrm{N} \\
-92^{\circ} \mathrm{W}\end{array}$ & $\begin{array}{l}35.903^{\circ} \mathrm{N} \\
-84.339^{\circ} \mathrm{W}\end{array}$ \\
\hline Years of operation & $2015-2025$ & 2004-2006 & 2009-2011 & $\begin{array}{l}\text { 2006-2013 } \\
\text { (detail } \\
\text { 2010-2013) }\end{array}$ & 1994 & $\begin{array}{l}\text { Various studies } \\
1994-2004\end{array}$ \\
\hline $\begin{array}{ll}\text { Differential } & \text { treat- } \\
\text { ments }\left(+{ }^{\circ} \mathrm{C}\right) & \end{array}$ & $\begin{array}{l}0^{*}, 2.25,4.5 \\
6.75,9\end{array}$ & $0^{*}, 5$ & $0^{*}, 1.8,3.5$ & $\begin{array}{l}0^{*}, \\
1.5 \text { Day/3.0 Night }\end{array}$ & $0^{*}, 1.6-4.1$ & $0 *, 3$ \\
\hline $\begin{array}{l}\text { Heated plot } \\
\text { area }\left(\mathrm{m}^{2}\right)\end{array}$ & 115.8 & 41.8 & 7.1 & 8.6 & 2.1 & 7.1 \\
\hline $\begin{array}{l}\text { Use of a constructed } \\
\text { control }\end{array}$ & Yes & Yes & Yes & Yes & $\mathrm{n} / \mathrm{a}$ & Yes \\
\hline $\begin{array}{l}\text { Season and diurnal } \\
\text { operation }\end{array}$ & $\begin{array}{l}365 \text { days, } \\
24 \mathrm{~h}\end{array}$ & $\begin{array}{l}\text { Heating treatments } \\
\text { applied when control } \\
\text { air }>0{ }^{\circ} \mathrm{C}\end{array}$ & $\begin{array}{l}\text { Warm season } \\
>1^{\circ} \mathrm{C} \quad(208 \text { to } \\
\left.244 \text { days } \mathrm{yr}^{-1}\right) ; 24 \mathrm{~h}\end{array}$ & $\begin{array}{l}365 \text { days, } \\
24 \mathrm{~h}\end{array}$ & $\begin{array}{l}365 \text { days, } \\
24 \mathrm{~h}\end{array}$ & $\begin{array}{l}365 \text { days, } \\
24 \mathrm{~h}\end{array}$ \\
\hline $\begin{array}{l}\text { Aboveground- } \\
\text { warming method }\end{array}$ & Heated air & Heated air & Infrared lamps & Infrared lamps & $\mathrm{n} / \mathrm{a}$ & Heated/cooled air \\
\hline $\begin{array}{l}\text { Air } T \text { method and } \\
\text { heights }\end{array}$ & $\begin{array}{l}\text { Thermistors at } 0.5,1 \text {, } \\
2(\times 2) \text {, and } 4 \mathrm{~m}\end{array}$ & $\begin{array}{l}\text { Thermocouples at } 1 \\
\text { and } 2.5 \mathrm{~m}\end{array}$ & $\begin{array}{l}\text { IR thermometer for } \\
\text { the canopy surface }\end{array}$ & $\begin{array}{l}\text { IR radiometers for the } \\
\text { canopy/soil surface; } \\
\text { thermocouples at } \\
+25 \mathrm{~cm},+15 \mathrm{~cm}(\times 2 \\
\text { within canopy) }\end{array}$ & $\mathrm{n} / \mathrm{a}$ & $\begin{array}{l}\text { Thermistor } \\
1 \mathrm{~m}\end{array}$ \\
\hline $\begin{array}{l}\text { Volume of heated } \\
\text { air surrounding } \\
\text { vegetation }\left(\mathrm{m}^{3}\right)\end{array}$ & $\sim 911$ & $\sim 209$ & Not assessed & Not achieved & $\mathrm{n} / \mathrm{a}$ & 17 \\
\hline $\begin{array}{l}\text { Belowground heating } \\
\text { method }\end{array}$ & $\begin{array}{l}\text { Resistance heaters at } \\
300 \mathrm{~cm} \text { depth in an } \\
\text { optimized pattern }\end{array}$ & $\begin{array}{l}\text { Buried cables at } \\
-20 \mathrm{~cm}, 30 \mathrm{~cm} \text { spac- } \\
\text { ing }\end{array}$ & $\begin{array}{l}\text { Buried cables at } \\
-10 \mathrm{~cm}, 20 \mathrm{~cm} \text { spac- } \\
\text { ing }\end{array}$ & $\mathrm{n} / \mathrm{a}$ & $\begin{array}{l}\text { IR Surface } \\
\text { warming }\end{array}$ & Air heating transfer \\
\hline $\begin{array}{l}\text { Soil } T \text { measurements } \\
\text { and depths }(\mathrm{cm})\end{array}$ & $\begin{array}{l}\text { Thermistors at } 0,-5 \\
-10,-20,-30,-40, \\
-50,-100, \\
-200 \text { at three loca- } \\
\text { tions in each plots }\end{array}$ & $\begin{array}{l}-2,-5,-10,-25 \\
-50,-100\end{array}$ & $\begin{array}{l}\text { Type } T \text { thermocou- } \\
\text { ples at } \\
-10 \text { and a subset at } \\
-20,-30,-50,-75, \\
-100\end{array}$ & $-0.5 \mathrm{~cm},-3 \mathrm{~cm}$ & $\begin{array}{l}\text { Thermocouple } \\
\text { at }-15 \mathrm{~cm}\end{array}$ & $\begin{array}{l}\text { Thermistor } \\
-10 \mathrm{~cm}\end{array}$ \\
\hline $\begin{array}{l}\text { Soil temp control } \\
\text { depth }(\mathrm{cm})\end{array}$ & -200 & -20 & -10 & $\mathrm{n} / \mathrm{a}$ & $\mathrm{n} / \mathrm{a}$ & $\mathrm{n} / \mathrm{a}$ \\
\hline $\begin{array}{l}\text { Full warming of soils } \\
\text { below } 1 \mathrm{~m}\end{array}$ & Achieved & $\mathrm{n} / \mathrm{a}$ & Partial warming & $\mathrm{n} / \mathrm{a}$ & $\mathrm{n} / \mathrm{a}$ & $\mathrm{n} / \mathrm{a}$ \\
\hline $\begin{array}{l}\text { Volume of } \\
\text { fully heated soil }\left(\mathrm{m}^{3}\right)\end{array}$ & 232 & $\mathrm{n} / \mathrm{a}$ & $\sim 2.1$ & $\mathrm{n} / \mathrm{a}$ & $\mathrm{n} / \mathrm{a}$ & $\mathrm{n} / \mathrm{a}$ \\
\hline $\mathrm{eCO}_{2}$ treatment & $+500 \mu \mathrm{mol} \mathrm{mol}^{-1}$ & None & None & $600 \mu \mathrm{mol} \mathrm{mol}^{-1}$ & None & $+300 \mu \mathrm{mol} \mathrm{mol}^{-1}$ \\
\hline $\begin{array}{l}\mathrm{eCO}_{2} \text { seasons of op- } \\
\text { eration }\end{array}$ & $\begin{array}{l}\text { Growing sea- } \\
\text { son/daytime }\end{array}$ & $\mathrm{n} / \mathrm{a}$ & $\mathrm{n} / \mathrm{a}$ & $\begin{array}{l}\text { Growing season, day- } \\
\text { time }\end{array}$ & $\mathrm{n} / \mathrm{a}$ & $\begin{array}{l}\text { Growing season, } \\
\text { daytime }\end{array}$ \\
\hline Other details & $\begin{array}{l}\text { Hydraulically isolated } \\
\text { to } 3 \text { to } 4 \mathrm{~m} \text { using a } \\
\text { sheet-pile corral }\end{array}$ & $\begin{array}{l}\text { Irrigated, VPD con- } \\
\text { trol with mist addition }\end{array}$ & Trenched & $\begin{array}{l}\text { Hydraulically isolated } \\
\text { to }-60 \mathrm{~cm}\end{array}$ & $\begin{array}{l}\text { Extracted } \\
\text { monoliths }\end{array}$ & Evaporative coolers \\
\hline No. plots operated & 10 & 8 & 72 & 10 & 27 & 12 \\
\hline Design & $\begin{array}{l}\text { Temperature } \\
\text { regression }\end{array}$ & $\begin{array}{l}2 \text { heat } \times 2 \text { irrigation, } \\
\text { randomized complete } \\
\text { block }\end{array}$ & $\begin{array}{l}2 \text { site } \times 2 \text { habitat } \\
\times 3 \text { temperature fac- } \\
\text { torial }\end{array}$ & $\begin{array}{l}2 \text { heat } \times 2 \mathrm{CO}_{2} \text { facto- } \\
\text { rial }\end{array}$ & $\begin{array}{l}2 \text { peatland types (bog } \\
\text { and fen) } \times 3 \text { heat } \times 3 \\
\text { water table factorial }\end{array}$ & $\begin{array}{l}\text { Various factorial } \\
\text { designs }\end{array}$ \\
\hline
\end{tabular}

* A differential treatment of 0 implies the inclusion of fully constructed controls. $n / a$ is not applicable; VPD is vapor pressure deficit. 


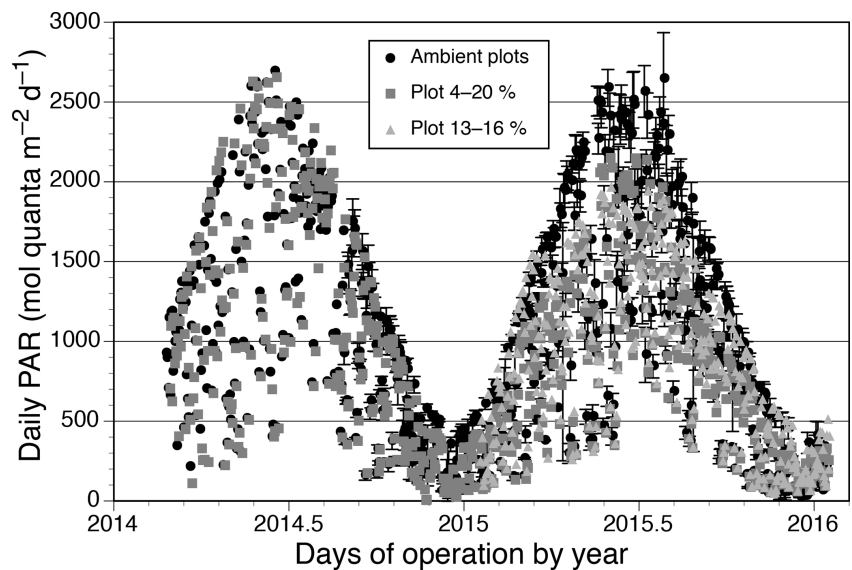

Figure 11. Example plot-center daily photosynthetically active radiation (PAR) at $2.5 \mathrm{~m}$ above the bog surface in 2014 before enclosures were installed and after enclosure additions in 2015 . The unchambered ambient plot data are from plot 7 (early in 2014) or the mean of plots 5, 7 and 21 with standard deviations shown. The figure legend shows the percent reduction in annual cumulative PAR associated with the presence of the enclosure infrastructure.
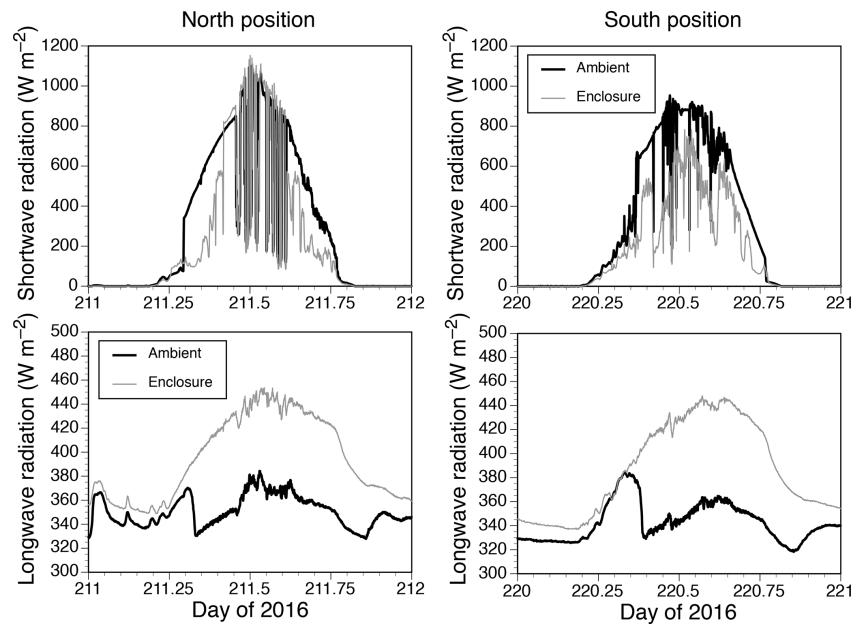

Figure 12. Example 1 min incident short (upper graphs) and longwave (lower graphs) radiation data at north and south positions within the plot 6 enclosure plotted against similar data collected in unchambered ambient conditions. All data were collected approximately $2 \mathrm{~m}$ above the surface of the S1-Bog boardwalks.

reasonably uniform heat from infrared lamps, the infrared method provides a viable field method for gathering temperature response data for vegetation and surface soil organisms.

The Hanson et al. (2011) deep-soil-warming protocols modified for SPRUCE are also being adopted in other recent ecosystem studies. Whole-soil and mesocosm warming experiments are being conducted in mineral soil (C. Hicks-Pries, personal communication, 2016), and a saltmarsh-warming study using a modification of the deepsoil heating approach has been initiated at the Smithso-
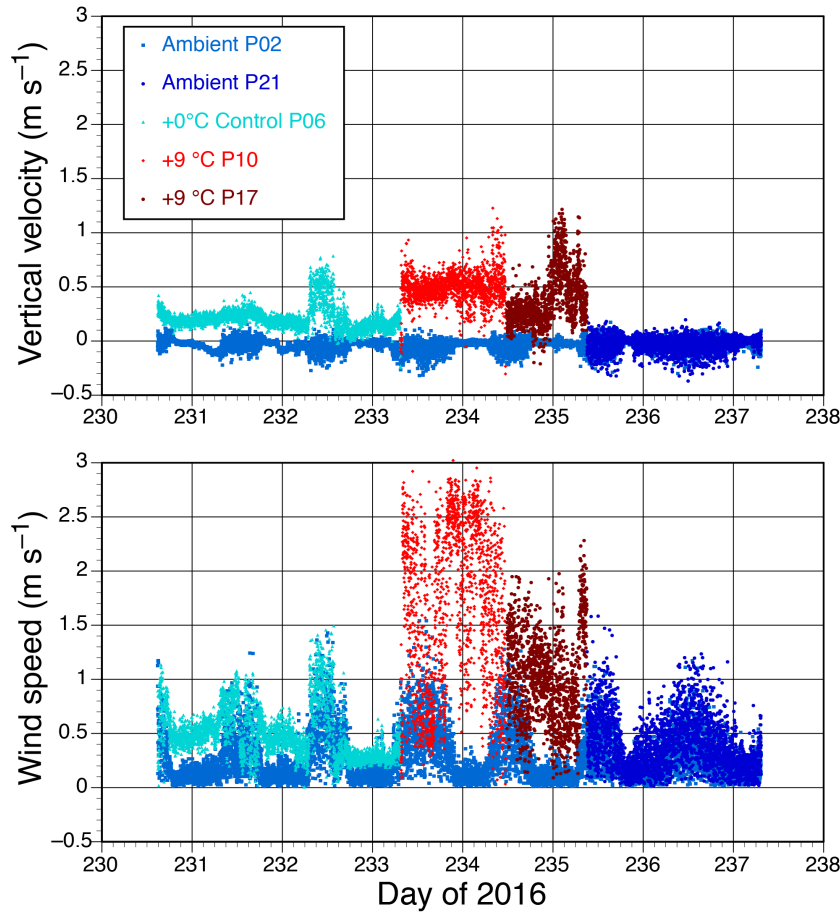

Figure 13. 1 min vertical wind velocity ( $U_{z}$; upper graph) and mean horizontal wind speed ( $U_{x}$ and $U_{y}$; lower graph) for unchambered ambient and enclosed plots of the SPRUCE study during the summer of 2016.

nian Ecological Research Center in Maryland (P. Megonigal, personal communication, 2016). Another approach has been to focus on single tree enclosures, as demonstrated by Medhurst et al. (2006), who used fully enclosed, aboveground whole-tree air warming of individual Picea abies trees $\left(8.3 \mathrm{~m}^{2}\right.$ plots $)$ maintained air at +2.8 to $+5.6{ }^{\circ} \mathrm{C}$, and included $\mathrm{eCO}_{2}$ control. That system has subsequently been deployed for Eucalyptus studies in Australia (Barton et al., 2010). The Medhurst approach was not fully integrated with belowground warming and associated processes, but it did allow for continuous assessments of the carbon exchange of the enclosed vegetation. Whole-enclosure carbon exchange calculations are planned for the SPRUCE study using a modified eddy flux constrained assessment for ambient- $\mathrm{CO}_{2}$ enclosures (L. Gu, personal communication, 2016).

Less technologically intense passive studies of warming, not covered in the reviews mentioned earlier, include a peat monolith transplant study down an elevation gradient allowing the characterization of $\mathrm{a}+5^{\circ} \mathrm{C}$ temperature change (Bragazza et al., 2016), a snow depth manipulation deployed in the arctic (Natali et al., 2011) and evaluations of thermal gradients around a geothermal source in Iceland (O'Gorman et al., 2015). While differing in plot sizes, level of aboveground and belowground temperature control or assessment, and the ability to standardize methods, these approaches rep- 

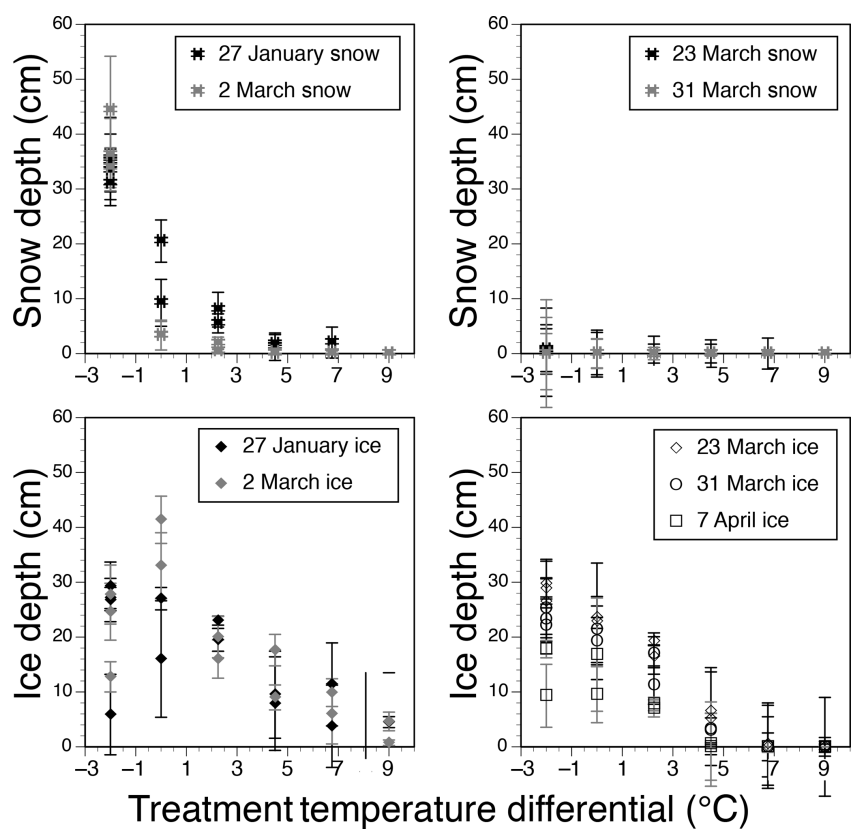

Figure 14. Snow depth (upper graphs) and ice depth (lower graphs) in each plot on 27 January and 2, 23, 31 March and 7 April 2016. All values are the mean depth \pm sd for four locations within replicate plots represented by the target treatment temperature differentials.

resent alternate methods from which to gather information on vegetation and microbial system responses to warming.

\subsection{Unique characteristics of the WEW method}

The following text describes and discusses the influence of the WEW enclosures and treatments on environmental variables that were altered from expected ambient conditions including light, wind, humidity, precipitation, ice and dew formation.

\subsubsection{Light}

The presence of greenhouse glazing and the enclosure structure reduced incident PAR at the center of the enclosures by around $20 \%$ during midday periods. This level of reduction is not sufficient to limit the photosynthetic capacity of the Picea foliage (Jensen et al., 2015) nor the other photosynthetic forms of vegetation being studied (J. Warren, personal communication, 2016). Reductions in shortwave radiation ranged from 24 to $41 \%$ and varied within the enclosure along a south to north gradient. Longwave or far infrared radiation representative of sky/cloud temperature conditions were $10 \%$ greater than for ambient conditions leading to less heat loss at night in constructed chambers when compared to unchambered ambient plots.
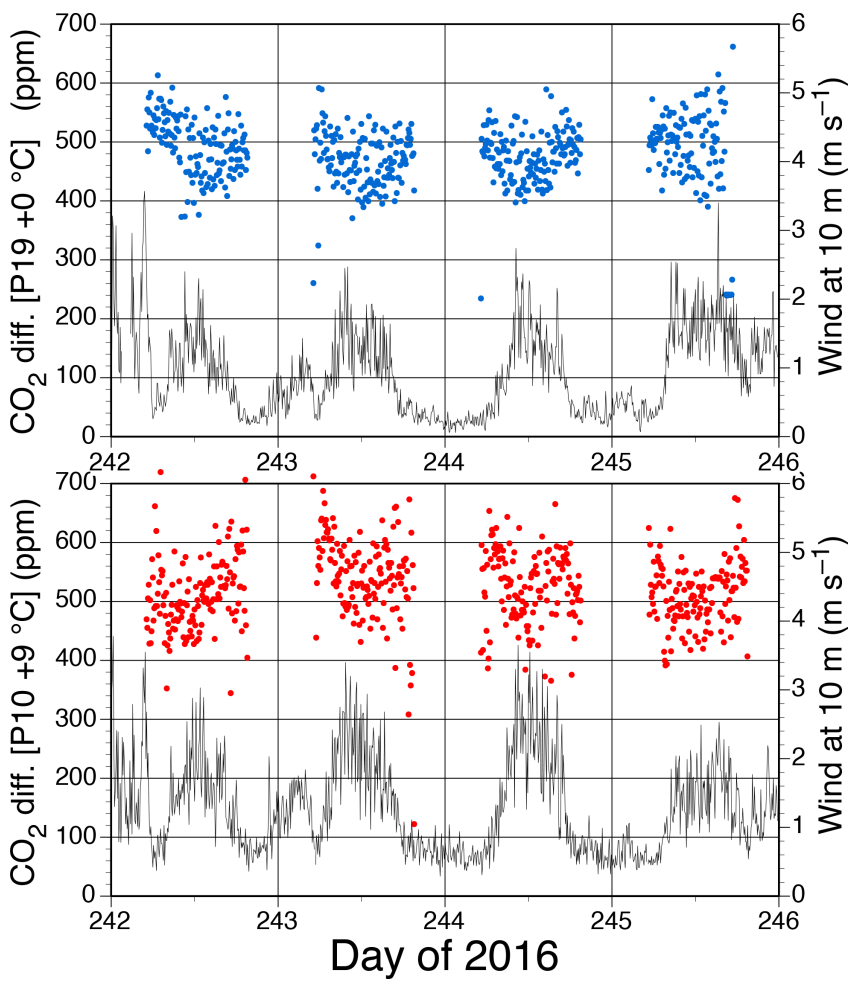

Figure 15. Examples of the differential $\mathrm{CO}_{2}$ concentrations achieved over 4 days in 2016 for a constructed control plot $\left(+0^{\circ} \mathrm{C}\right.$; upper graph) and plot warmed to $+9^{\circ} \mathrm{C}$. All point data are $6 \mathrm{~min}$ running mean $\left[\mathrm{CO}_{2}\right]$ differentials plotted with their respective $6 \mathrm{~min}$ running mean $10 \mathrm{~m}$ wind speed data.

\subsubsection{Wind}

The increase in enclosure turbulence in warming and control plots is driven by forced-air movement from the hot air blower system, and confounded by the influence of vertical warm air buoyancy. Increased horizontal turbulence is present in the unheated control enclosures $(0.14 \pm 0.24$ to $\left.0.31 \pm 0.23 \mathrm{~m} \mathrm{~s}^{-1}\right)$, and much larger in the $+9^{\circ} \mathrm{C}$ heated chambers $\left(0.8 \pm 0.4\right.$ to $\left.1.3 \pm 0.9 \mathrm{~m} \mathrm{~s}^{-1}\right)$. Vertical velocities $\left(U_{z}\right)$ in the control and $+9^{\circ} \mathrm{C}$ plots, show increases of $0.26 \pm 0.18 \mathrm{~m} \mathrm{~s}^{-1}$ for the plot 6 control, and for the $\pm 9^{\circ} \mathrm{C}$ treatment enclosures $0.55 \pm 0.14 \mathrm{~m} \mathrm{~s}^{-1}$ for plot 10 and $0.41 \pm 0.24 \mathrm{~m} \mathrm{~s}^{-1}$ for plot 17. A more detailed analysis of turbulence patterns across the full range of warming enclosures will be evaluated in the future with planned deployment of eddy flux instrument packages within the ambient- $\mathrm{CO}_{2}$ enclosures for whole-enclosure-footprint $\mathrm{CO}_{2}$ - and $\mathrm{CH}_{4}$-flux measurements.

\subsubsection{Atmospheric humidity}

Warming of the enclosure using air containing consistent absolute humidity (Supplement Fig. S7) led to proportionate reductions in relative humidity (Table 4) and sustained a higher 
gradient of vapor pressure between the well-mixed enclosure air and wetter soil and plant surfaces. Although not to the levels induced by the SPRUCE treatments, the most recent IPCC report (Collins et al., 2013) concluded that relative humidity over interior continental regions could be projected to drop with future warming. Some prior warming studies have considered how to ameliorate this drop in humidity and reduction in soil water use by use of a steam/misting system or irrigation in warmed plots (e.g., Bronson et al., 2008, 2009; de Boeck et al., 2012).

Adding steam to sustain relative humidity within small open-topped warming chambers was shown to be technologically feasible (Hanson et al., 2011); however, it was not considered for deployment at SPRUCE due to the requisite energy costs and water volume requirements. For example, let us assume a mid-summer condition $\left(25^{\circ} \mathrm{C}, 97 \mathrm{kPa}, 90\right.$ $100 \%$ day/night RH) and continuous operation of our $911 \mathrm{~m}^{3}$ open-top enclosures at $+9^{\circ} \mathrm{C}$ with a mean external wind velocity of $2 \mathrm{~m} \mathrm{~s}^{-1}$, an enclosure turnover fraction of approximately 0.62 (actually external winds and turnover fractions are often much greater) and a day/night RH of $47 / 70 \%$. Under these conditions, a water source of $9.7 \mathrm{~m}^{3} \mathrm{~d}^{-1}$ would have been needed for routine operations along with additional energy to convert it to steam would have been required to sustain the ambient relative humidity of $90 \%$ within the $+9^{\circ} \mathrm{C}$ enclosure. Such a distilled water supply (necessary to limit corrosion and nutrient transfers to the ecosystem) and energy supplies made RH control too expensive. A mistbased approach for controlling humidity in a free-air environment has been reported (Kupper et al., 2011), but such a system would still require the availability of a significant treated water source and would increase the air-warming heating demands necessary to sustain our air-warming differential temperatures due to the latent heat absorbed by evaporating droplets.

Choosing to operate our WEW system with variable relative humidity led to greater proportional surface evaporation from Sphagnum (essentially all ground cover), water use by $\mathrm{C} 3$ plants and an expected reduction in the seasonal water table with warming. In the first season of operation, reductions in water table depths were limited as the corralled plots were left undrained and ambient rainfall inputs exceeded losses from evapotranspiration. Since relative humidity was allowed to vary with treatments in SPRUCE, significant effort was invested in fully quantifying the impact on changing surface sphagnum and peat water content, plot level water balance, and water table depth within each enclosure (Fig. S2).

\subsubsection{Precipitation and winter ice}

Although the frustum encircling the top of the enclosure does create an internal rain and snow shadow over the internal boardwalk, the excluded rain runs down the enclosure walls onto the peat surface inside of the corral barrier. As a result, there is a rain shadow impact for some edge vegetation, but the overall water inputs to the plot remain the same as for an unchambered ambient plot (data not shown). The frustum does, however, reduce winter snow accumulation within the plot because some snow is thrown clear of the subsurface corral (Fig. 14). However, ice formation in the surface peat of the control plots was similar to or greater than that found beneath unchambered ambient plots (Fig. 14).

Changes to the energy balance due to the presence of the enclosure (described above) have a large impact on snow depth between unchambered ambient and enclosed plots. Simulations with the CLM-SPRUCE model indicate that on average, the snow depth is reduced by $40 \%$ in enclosed vs. unchambered ambient plots, with the highest reductions in the late winter and early spring. Complete loss of snowpack generally occurs $2-3$ weeks earlier when the effects of the enclosure are considered. The observed reductions are slightly larger, reflecting enclosure snow shadowing effects and potentially higher sublimation caused by increased air movement not considered in the simulations. Despite the reduction in snow cover, the simulated ice depth is similar between the unchambered ambient and enclosed plots - and this correlates well with our in situ observations (Fig. 14). The warming of the peat layers caused by increased longwave input is likely compensated to a large degree by increased heat loss during cold snaps because of the reduction of insulating snowpack, an effect that was explained in more detail in Shi et al. (2015).

\subsubsection{Lack of dew formation}

Even without active warming, modifications to the energy balance caused by the enclosures lead to warming effects that influence air and vegetation temperatures, dew formation and snow dynamics. The incoming longwave radiation within the enclosure is significantly elevated, especially in clear-sky conditions. Simulations with the CLM-SPRUCE model (Shi et al., 2015) were conducted to investigate the effects of SPRUCE enclosures on changes in the energy balance on dew formation, snowpack and soil ice. Simulated average $+2 \mathrm{~m}$ air temperatures within the enclosures are about $0.8^{\circ} \mathrm{C}$ warmer than the unchambered ambient plots (Fig. 16).

This warming effect is highly variable, ranging from nearly 0 to over $5^{\circ} \mathrm{C}$, and is largest in the early morning under clear conditions, when radiation cooling is inhibited most by the enclosure walls, and during the winter months when longwave radiation is a larger fraction of the overall radiation budget. While the observed differences follow this general pattern, they are more than double the simulated magnitudes. This may be due to the model ignoring the impacts of the enclosure on wind speed and turbulence patterns, which cannot be considered in these simulations because the assumptions in CLM-SPRUCE about Monin-Obukhov similarity and logarithmic wind profiles (Oleson et al., 2013) that cannot easily be extended to the SPRUCE conditions. Simulated leaf sur- 


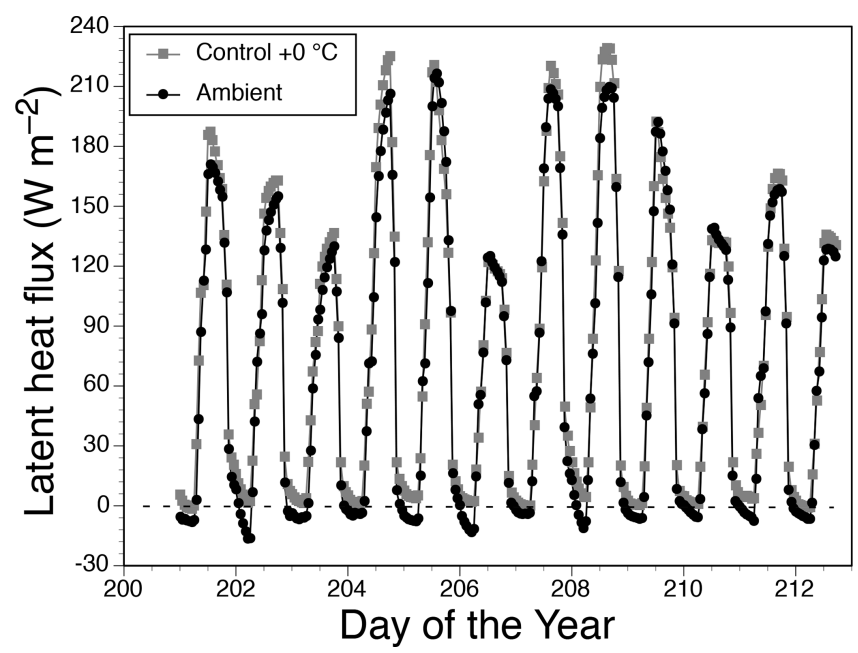

Figure 16. Simulations of latent heat flux over a 10-day period for ambient conditions (black) and in a control enclosure (gray) using environmental driver meteorology data from July 2013. Negative latent heat fluxes indicate dew formation, but only occur for the ambient condition.

face temperatures in the enclosures were elevated on average by $2.5^{\circ} \mathrm{C}$, which has important implications for carbon and energy fluxes.

Despite underestimating air warming in the simulation, the model results indicated a near-complete inhibition of dew formation (Fig. 16), similar to site observations. Total dew formation was about $12 \mathrm{~mm}$ integrated over the growing season (May-September) in the ambient simulation, but only $0.5 \mathrm{~mm}$ in the enclosure simulation (96\% reduction). In the simulations, this resulted from higher surface temperatures and lower relative humidity. Near-surface wind speeds in the enclosures are also usually higher than for unchambered ambient areas as a result of the blowers. This turbulence likely further inhibits the formation of dew, but such an effect was not considered in the CLM simulations.

\section{Conclusions}

The WEW system described is capable of providing a broad range of warming conditions up to $+9{ }^{\circ} \mathrm{C}$ with minimal artifacts from the experimental infrastructure. The end result is an experiment system capable of giving scientists a fair glimpse of organism and ecosystem responses for plausible future warming scenarios that cannot be measured today or extracted from the historical record. The large SPRUCE enclosures allow for ongoing ecosystem-level assessments of warming responses for vegetation growth and mortality, phenology changes, changing microbial community composition and function, biogeochemical cycles and associated net greenhouse gas emissions.

\section{Data availability}

The environmental measurement data referenced in this paper are archived at and available from the SPRUCE longterm repository (Hanson et al., 2016; http://mnspruce.ornl. gov).

\section{The Supplement related to this article is available online at doi:10.5194/bg-14-861-2017-supplement.}

Author contributions. Paul J. Hanson conceived the experimental methods and wrote this paper. Charlotte Barbier optimized the airwarming system using complex fluid dynamics models. Jeffery S. Riggs programmed the SPRUCE enclosure feedback control systems. Misha B. Krassovski designed and maintained the local and satellite communications systems. Paul J. Hanson, W. Robert Nettles, Jana R. Phillips, Jeffery S. Riggs and Jeffrey M. Warren installed and maintain instrumentation. Andrew D. Richardson supplied installed and monitored plot phenology cameras. Donald M. Aubrecht evaluated light transmission characteristics of the enclosure sheathing. Lianhong $\mathrm{Gu}$ interpreted wind velocity and speed data. Daniel M. Ricciuto executed runs of the CLM-SPRUCE model to interpret enclosure energy balance properties. Leslie A. Hook archived data. All authors have read, understand and agree to the content of this paper.

Competing interests. The authors declare that they have no conflict of interest.

Disclaimer. This material is based upon work supported by the US Department of Energy, Office of Science, Office of Biological and Environmental Research. Oak Ridge National Laboratory is managed by UT-Battelle, LLC, for the US Department of Energy under contract DE-AC05-00OR22725. The development of PhenoCam IT infrastructure was supported by the National Science Foundation's Macrosystems Biology program (award EF-1065029). The views expressed in this article do not necessarily represent the views of the US Department of Energy or the United States Government.

Acknowledgements. The authors would like to thank Randall K. Kolka, USDA Forest Service, Northern Research Station for working in collaboration with the Oak Ridge National Laboratory to enable access to and use of the S1-Bog of the Marcell Experimental Forest for the SPRUCE experiment and affiliated studies. We would also like to thank Natalie A. Griffiths, Stan D. Wullschleger and Randall K. Kolka for their comments on early drafts, as well as editorial assistance provided by Terry Pfeiffer.

Edited by: P. Stoy

Reviewed by: two anonymous referees 


\section{References}

Amthor, J. S., Hanson, P. J., Norby, R. J., and Wullschleger, S. D.: A comment on "Appropriate experimental ecosystem warming methods by ecosystem, objective, and practicality" by Aronson and McNulty, Agr. Forest Meteorol., 150, 497-498, 2010.

Aronson, E. L. and McNulty, S. G.: Appropriate experimental ecosystem warming methods by ecosystem, objective and practicality, Agr. Forest Meteorol., 149, 1791-1799, 2009.

Baker, D. G. and Ruschy, D. L.: The recent warming in eastern Minnesota shown by ground temperatures, Geophys. Res. Lett., 20, 371-374, doi:10.1029/92GL02724, 1993.

Barbier, C., Hanson, P. J., Todd Jr., D. E., Belcher, D., Jekabson, E. W., Thomas, W. K., and Riggs, J. S.: Air Flow and Heat Transfer in a Temperature Controlled Open Top Enclosure, ASME International Mechanical Engineering Congress and Exposition, 2012, Houston, TX, Paper \#IMECE2012-86352, 2012.

Barton, C. V. M., Ellsworth, D. S., Medlyn, B. E., Duursma, R. A., Tissue, D. T., Adams, M. A., Eamus, D., Conroy, J. P., McMurtrie, R. E., Parsbyg, J., and Linder, S.: Whole-tree chambers for elevated atmospheric $\mathrm{CO}_{2}$ experimentation and tree scale flux measurements in south-eastern Australia: The Hawkesbury forest experiment, Agr. Forest Meteorol., 150, 941-951, 2010.

Bragazza, L., Buttler, A., Robroek, B. J. M., Albrecht, R., Zaccone, C., and Jassey, V. E. J.: Persistent high temperature and low precipitation reduce peat carbon accumulation, Glob. Change Biol., 22, 3253-3254, doi:10.1111/gcb.13319, 2016.

Bridgham, S. D., Pastor, J., Updegraf, K., Malterer, T. J., Johnson, K., Harth, C., and Chen, J.: Ecosystem control over temperature and energy flux in northern peatlands, Ecol. Appl., 9, 1345-1358, 1999.

Bridgham, S. D., Megonigal, J. P., Keller, J. K., Bliss, N. B., and Trettin, C.: The carbon balance of North American wetlands, Wetlands, 26, 889-916, 2006.

Bronson, D. R., Gower, S. T., Tanner, M., Linder, S., and Van Herk, I.: Response of soil surface $\mathrm{CO}_{2}$ flux in a boreal forest to ecosystem warming, Glob. Change Biol., 14, 856-867, 2008.

Bronson, D. R., Gower, S. T., Tanner, M., and Van Herk, I.: Effect of ecosystem warming on boreal black spruce bud burst and shoot growth, Glob. Change Biol., 15, 1534-1543, 2009.

Cavaleri, M. A., Reed, S. C., Smith, W. K., and Wood, T. E.: Urgent need for warming experiments in tropical forests, Glob. Change Biol., 21, 2111-2121, doi:10.1111/gcb.12860, 2015.

Collins, M., Knutti, R., Arblaster, J., Dufresne, J.-L., Fichefet, T., Friedlingstein, P., Gao, X., Gutowski, W. J., Johns, T., Krinner, G., Shongwe, M., Tebaldi, C., Weaver, A. J., and Wehner, M.: Long-term Climate Change: Projections, Commitments and Irreversibility, in: Climate Change 2013: The Physical Science Basis. Contribution of Working Group I to the Fifth Assessment Report of the Intergovernmental Panel on Climate Change, edited by: Stocker, T. F., Qin, D., Plattner, G.-K., Tignor, M., Allen, S. K., Boschung, J., Nauels, A., Xia, Y., Bex, V., and Midgley, P. M., Cambridge University Press, Cambridge, United Kingdom and New York, NY, USA, 2013.

Cottingham, K. L., Lennon, J. T., and Brown, B. L.: Knowing when to draw the line: designing more informative ecological experiments, Front. Ecol. Environ., 3, 145-152, 2005.

Cramer, W., Bondeau, A., Woodward, F. I., Prentice, I. C., Betts, R. A., Brovkin, V., Cox, P. M., Fisher, V., Foley, J. A., Friend, A. D., Kucharik, C., Lomas, M. R., Ramankutty, N., Sitch, S.,
Smith, B., White, A., and Young-Molling, C.: Global response of terrestrial ecosystem structure and function to $\mathrm{CO}_{2}$ and climate change: results from six dynamic global vegetation models, Glob. Change Biol., 7, 357-373, 2001.

Davidson, E. A. and Janssens, I. A.: Temperature sensitivity of soil carbon decomposition and feedbacks to climate change, Nature, 440, 165-173, 2008.

de Boeck, H. J., Kimball, B. A., Miglietta, F., and Nijs, I.: Quantification of excess water loss in plant canopies warmed with infrared heating, Glob. Change Biol., 18, 2860-2868, 2012.

Dickson, R. E., Lewin, K. F., Isebrands, J. G., Coleman, M. D., Heilman, W. E., Riemenschneider, D. E., Sober, J., Host, G. E., Zak, D. R., Hendrey, G. R., Pregitzer, K. S., and Karnosky, D. F.: Forest atmosphere carbon transfer and storage (FACTS-II) the aspen Free-air $\mathrm{CO}_{2}$ and $\mathrm{O}_{3}$ Enrichment (FACE) project: an overview, Gen Tech. Rep. NC-214. St. Paul, MN, U.S. Department of Agriculture, Forest Service, North Central Research Station, 68 pp., 2000.

Hanson, P. J., Classen, A., Kueppers, L., Luo, Y., McDowell, N. G., Morris, J., Rogers, A., Thornton, P., Ceulemans, R., Dukes, J., Goulden, M., Jackson, R., Knapp, A., Kirschbaum, M., Lewin, K., MacCracken, M., Melillo, J., Ringler, R., and Workshop Participants: Ecosystem Experiments: Understanding Climate Change Impacts On Ecosystems and Feedbacks to the Physical Climate, Workshop Report on Exploring Science Needs for the Next Generation of Climate Change and Elevated $\mathrm{CO}_{2}$ Experiments in Terrestrial Ecosytems, 14 to 18 April 2008, Arlington, Virginia, available at: http://science.energy.gov/ /media/ber/ pdf/Ecosystem_experiments.pdf (last access: 21 February 2017), 2008.

Hanson, P. J., Childs, K. W., Wullschleger, S. D., Riggs, J. S., Thomas, W. K., Todd, D. E., and Warren, J. M.: A method for experimental heating of intact soil profiles for application to climate change experiments, Glob. Change Biol., 17, 1083-1096, 2011.

Hanson, P. J., Riggs, J. S., Nettles, W. R., Krassovski, M. B., and Hook, L. A.: SPRUCE Whole Ecosystems Warming (WEW) Environmental Data Beginning August 2015, Carbon Dioxide Information Analysis Center, Oak Ridge National Laboratory, U.S. Department of Energy, Oak Ridge, Tennessee, USA, doi:10.3334/CDIAC/spruce.032, 2016.

Harte, J., Torn, M. S., Chang, F.-R., Feifarek, B., Kinzig, A. P., Shaw, R., and Shen, K.: Global warming and soil microclimate: results from a meadow-warming experiment, Ecol. Appl., 5, 132-150, 1995.

Huang, S.: Land warming as part of global warming, EOS, 87, 477480, 2006.

IPCC: Climate Change 2014: Impacts, Adaptation, and Vulnerability. Part B: Regional Aspects. Contribution of Working Group II to the Fifth Assessment Report of the Intergovernmental Panel on Climate Change, edited by: Barros, V. R., Field, C. B., Dokken, D. J., Mastrandrea, M. D., Mach, K. J., Bilir, T. E., Chatterjee, M., Ebi, K. L., Estrada, Y. O., Genova, R. C., Girma, B., Kissel, E. S., Levy, A. N., MacCracken, S., Mastrandrea, P. R., and White, L. L., Cambridge University Press, Cambridge, United Kingdom and New York, NY, USA, 688 pp., 2014.

Jensen, A. M., Warren, J. M., Hanson, P. J., Childs, J., and Wullschleger, S. D.: Needle age and season influence photosynthetic temperature response and total annual carbon uptake in 
mature Picea mariana trees, Ann. Bot.-London, 116, 821-832, doi:10.1093/aob/mcv115, 2015.

Kardol, P., De Long, J. R., and Sundqvist, M. K.: Crossing the threshold: the power of multi-level experiments in identifying global change responses, New Phytol., 196, 323-326, 2012.

Kayler, Z. E., De Boeck, H. J., Fatichi, S., Grünzwig, J. M., Merbold, L., Beier, C., McDowell, N., and Dukes, J. S.: Experiments to confront the environmental extremes of climate change, Front. Ecol. Environ., 13, 219-225, doi:10.1890/140174, 2015.

Keenan, T. F., Darby, B., Felts, E., Sonnentag, O., Friedl, M., Hufkens, K., O'Keefe, J., Klosterman, S., Munger, J. W., Toomey, M., and Richardson, A. D.: Tracking forest phenology and seasonal physiology using digital repeat photography: a critical assessment, Ecol. Appl., 24, 1478-1489, doi:10.1890/130652.1, 2014.

Kimball, B. A.: Comment on the comment by Amthor et al., on "Appropriate experimental ecosystem warming methods" by Aronson and McNulty, Agr. Forest Meteorol., 151, 420-424, 2011.

Kimball, B. A., Conley, M. M., Wang, S., Lin, X., Luo, C., Morgan, J., and Smith, D.: Infrared heater arrays for warming ecosystem field plots, Glob. Change Biol., 14, 309-320, doi:10.1111/j.13652486.2007.01486.x, 2008.

Kolka, R. K., Sebestyen, S. D., Verry, E. S., and Brooks, K. N.: Peatland biogeochemistry and watershed hydrology at the Marcell Experimental Forest, CRC Press, Boca Raton, 488 pp., 2011.

Krassovski, M. B., Riggs, J. S., Hook, L. A., Nettles, W. R., Hanson, P. J., and Boden, T. A.: A comprehensive data acquisition and management system for an ecosystem-scale peatland warming and elevated $\mathrm{CO}_{2}$ experiment, Geosci. Instrum. Method. Data Syst., 4, 203-213, doi:10.5194/gi-4-203-2015, 2015.

Kupper, P., Sõber, J., Sellin, A., Lõhmus, K., Tullus, A., Räim, O., Lubenets, K., Tulva, I., Uri, V., Zobel, M,, Kull, O., and Sõber, A.: An experimental facility for free humidity manipulation (FAHM) can alter water flux through deciduous tree canopy, Environ. Exp. Bot., 72, 432-438, 2011.

LeCain, D., Smith, D., Morgan, J., Kimball, B. A., Pendall, E., and Miglietta, F.: Microclimatic Performance of a Free-Air Warming and $\mathrm{CO}_{2}$ Enrichment? Experiment in Windy Wyoming, USA, PLoS ONE, 10, e0116834. doi:10.1371/journal.pone.0116834, 2015.

Leuzinger, S., Fatichi, S., Cusens, J., Körner, C., and Niklaus, P. A.: The "island effect" in terrestrial global change experiments: a problem witih no solution?, AoB Plants, 7, plv092, doi:10.1093/aobpla/plv092, 2015.

Medhurst, J., Parsby, J., Linder, S., Wallin, G., Ceschia, E., and Slaney, M.: A whole-tree chamber system for examining treelevel physiological responses of field-grown trees to environmental variation and climate change, Plant Cell Environ., 29, 1853 $1869,2006$.

Medlyn, B. E., Zaehle, S., De Kauwe, M. G., Walker, A. P., Dietze, M. C., Hanson, P. J., Hickler, T., Jain, A. K., Luo, Y., Parton, W., Prentice, I. C., Thornton, P. E., Wang, S., Wang, Y.P., Weng, E., Iversen, C. M., McCarthy, H. R., Warren, J. M., Oren, R., and Norby, R. J.: Using ecosystem experiments to improve vegetation models, Nature Climate Change, 5, 528-534, doi:10.1038/NCLIMATE2621, 2015.

Natali, S. M., Schuur, E. A. G., Trucco, C., Hicks Pries, C. E., Crummer, K. G., and Baron Lopez, A. F.: Effects of experimental warming of air, soil and permafrost on carbon balance in Alaskan tundra, Glob. Change Biol., 17, 1394-1407, 2011.

Norby, R. J., Edwards, N. T., Riggs, J. S., Abner, C. H., Wullschleger, S. D., and Gunderson, C. A.: Temperaturecontrolled open-top chambers for global change research, Glob. Change Biol., 3, 259-267, 1997.

O’Gorman, E. J., Benstead, J. P., Cross, W. F., Friberg, N., Hood, J. M., Johnson, P. W., Sigurdsson, B. D., and Woodward, G.: Climate change and geothermal ecosystems: natural laboratories, sentinel systems, and future refugia, Glob. Change Biol., 20, 3291-3299, doi:10.1111/gcb.12602, 2015.

Oleson, K. W., Lawrence, D. M., Bonan, G. B., Drewniak, B., Huang, M., Koven, C. D., Levis, S., Li, F., Riley, W. J., Subin, Z. M., Swenson, S. C., Thornton, P. E., Bozbiyik, A., Fisher, R., Heald, C. L., Kluzek, E., Lamarque, J.-F., Lawrence, P. J., Leung, L. R., Lipscomb, W., Muszala, S., Ricciuto, D. M., Sacks, W., Sun, Y., Tang, Y., and Yang, Z.-L.: Technical Description of version 4.5 of the Community Land Model (CLM), National Center for Atmospheric Research, Boulder, Colorado, NCAR/TN503+STR NCAR Technical Note, July 2013.

Parsekian, A. D., Slater, L., Ntarlagiannis, D., Nolan, J., Sebestyen, S. D., Kolka, R. K., and Hanson, P. J.: Uncertainty in peat volume and soil carbon estimated using ground-penetrating radar and probing, Soil Sci. Soc. Am. J., 76, 1911-1918, doi:10.2136/sssaj2012.0040, 2012.

Petach, A. R., Toomey, M., Aubrecht, D. M., and Richardson, A. D.: Monitoring vegetation phenology using an infraredenabled security camera, Agr. Forest Meteorol., 195-196, 143151, doi:10.1016/j.agrformet.2014.05.008, 2014.

Qi, Y., Heisler, G. M., Gao, W., Vogelmann, T. C., and Bai, S.: Characteristics of UV-B Radiation Tolerance in Broadleaf Trees in Southern USA, chapt. 18, 509-530, in: UV Radiation in Global Climate Change: Measurements, Modeling and Effects on Ecosystems, edited by: Gao, W., Schmoldt, D. L., and Slusser, J. R., Tsinghua University Press and Springer, 2010.

Raupach, M. R., Marland, G., Ciais, P., Le Queré, C., Canadell, J. G., Klepper, G., and Field, C. B.: Global and regional drivers of accelerating $\mathrm{CO}_{2}$ emissions, Proc. Natl. Acad. Sci. USA, 104, 10288-10293, 2007.

Rich, R. L., Stefanski, A., Montgomery, R. A., Hobbie, S. E., Kimball, B. A., and Reich, P. B.: Design and performance of combined infrared canopy and belowground warming in B4WarmED (Boreal Forest Warming at an Ecotone in Danger) experiment, Glob. Change Biol., 21, 2334-2348, doi:10.1111/gcb.12855, 2015.

Rustad, L. E., Campbell, J. L., Marion, G. M., Norby, R. J., Mitchell, M. J., Hartley, A. E., Cornelissen, J. H. C., and Gurevitch, J., GCTE-NEWS: A meta-analysis of the response of soil respiration, net nitrogen mineralization, and aboveground plant growth to experimental ecosystem warming, Oecologia, 126, 543-562, doi:10.1007/s004420000544, 2001.

Sebestyen, S. D. and Griffiths, N. A.: SPRUCE Enclosure Corral and Sump System: Description, Operation, and Calibration. Climate Change Science Institute, Oak Ridge National Laboratory, U.S. Department of Energy, Oak Ridge, Tennessee, USA, available at: http://dx.doi.org/10.3334/CDIAC/spruce.030 (last access: 21 February 2017), 2016.

Sebestyen, S. D., Dorrance, C., Olson, D. M., Verry, E. S., Kolka, R. K., Elling, A. E., and Kyllander, R.: Chapter 2: Long-term mon- 
itoring sites and trends at the Marcell Experimental Forest, in: Peatland biogeochemistry and watershed hydrology at the Marcell Experimental Forest, edited by: Kolka, R. K., Sebestyen, S. D., Verry, E. S., and Brooks, K. N., CRC Press, New York, 1572, 2011.

Shaver, G. R., Canadell, J., and Chapin III, F. S.: Global warming and terrestrial ecosystems: a conceptual framework for analysis, Bioscience, 50, 871-882, 2000.

Shi, X., Thornton, P. E., Ricciuto, D. M., Hanson, P. J., Mao, J., Sebestyen, S. D., Griffiths, N. A., and Bisht, G.: Representing northern peatland microtopography and hydrology within the Community Land Model, Biogeosciences, 12, 6463-6477, doi:10.5194/bg-12-6463-2015, 2015.

Strack, M.: Peatlands and Climate Change, International Peat Society, Jyväskylä, Finland, 223 pp., 2008.

Tfaily, M. M., Cooper, W. T., Kostka, J., Chanton, P. R., Schadt, C. W., Hanson, P. J., Iversen, C. M., and Chanton, J. P.: Organic matter transformation in the peat column at Marcell Experimental Forest: humification and vertical stratification, J. Geophys. ResBiogeo., 119, 661-675, doi:10.1002/2013JG002492, 2014.
Toomey, M., Friedl, M. A., Frolking, S., Hufkens, K., Klosterman, S., Sonnentag, O., Baldocchi, D. D., Bernacchi, C. J., Biraud, S. C., Bohrer, G., Brzostek, E., Burns, S. P., Coursolle, C., Hollinger, D. Y., Margolis, H. A., McCaughey, H., Monson, R. K., Munger, J. W., Pallardy, S., Phillips, R. P., Torn, M. S., Wharton, S., Zeri, M., and Richardson, A. D.: Greenness indices from digital cameras predict the timing and seasonal dynamics of canopy-scale photosynthesis, Ecol. Appl., 25, 99-115, doi:10.1890/14-0005.1, 2015.

Torn, M. S., Chabbi, A., Crill, P., Hanson, P. J., Janssens, I. A., Luo, Y., Pries, C. H., Rumpel, C., Schmidt, M. W. I., Six, J., Schrumpf, M., and Zhu, B.: A call for international soil experiment networks for studying, predicting, and managing global change impacts, SOIL, 1, 575-582, doi:10.5194/soil-1-575-2015, 2015.

Verry, E. S., Brooks, K. N., and Barten, P. K.: Streamflow response from an ombrotrophic mire, in: Symposium on the hydrology of wetlands in temperate and cold regions, Publications of the Academy of Finland, Helsinki, 52-59, 1988.

Walther, G.-R., Post, E., Convey, P., Menzel, A., Parmeson, C., Beebee, T. J. C., Fromenten, J.-M., Hoegh-Guldberg, O., and Bairlein, F.: Ecological responses to recent climate change, Nature, 416, 389-395, 2002. 